\title{
委員会報告
}

\section{RI 体外測定装置の性能検査法}

\author{
放射性同位元素検査技術委員会 \\ 委員 長 大谷 英尚（東京女子医科大学） \\ 委員 (班長) 山 本 洋 一（神奈川県立成人病センター） \\ 喜多村 道 男 (三井記念病院) \\ 関守 男 (埼玉医科大学) \\ 蜂 谷 武 憲（秋田県立脳血管研究センター） \\ 長谷川＼cjkstart武（川崎市立川崎病院）
}

\section{はじめに}

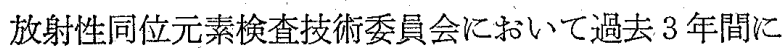
RI 体外測定装置の性能検查法について 検討を加えてき た。ここに一応の成案を得たので報告する。

この性能検查法は RI 体外測定装置の日常の性能管理, 装置購入時の性能チェック，研究発表等の性能検査法の 統一を目的として作成されたものである。

この検查方法自体についても多くの問題点があり，完 全なるのではない，利用者各位の協力を得て，より良い 検查方法の確立のための礎となることを希望する。

この検查方法の他に核医学イメージ規格化小委員会の 「シンチカメラの性能試験条件」と IEC のドラフト (SC-62C) である「Characteristic and test conditions of radionuclide imaging devices」があるので参考にさ れたい。

この検査法の作成にあたって，多数の会員の方々から
意見や問題点を指摘していただいた事に感謝の意を表す る次第である。

本検查方法はシンチスキャナ，シンチカメラ，動態機 能検查装置の各装置について必要な検查項目々検查方法 が列挙してある．検查項目については非常に面倒で長時 間の測定時間が必要な物や，特殊な測定器具等の必要な 項目も含まれている。但し，日常の性能管理等について はこれらの全項目を検査する必要はなく，それぞれの使 用現場の実状に応じた検查方法を採用されることを希望 する。

特に装置購入時の性能検査については敩密なチェック を行ない，その記録がそれ以後の性能管理の基本となる。 本検查方法は臨床条件に対応する意味で原則としてフ アントムは水または水等価物質等を使用し，その他の設 定条件子臨床検查条件と同一になるようにした。

最後に委員が所属する職場の方々にデータ作成につい て多大の衔援助をいただいた事を附記する。

\section{I ．シンチスキャナの性能検査法}

シンチスキャナは，1951年米国の Cassen らによって

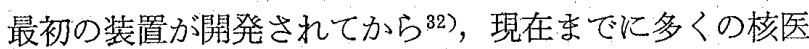
学検查に利用されてきた，すで周知のごとくスキャナ は，検查部位をスキャンすること，Display が機栰的要
素を有する点で, シンチカメラとは買なる，従ってこれ らを考虑し，その重要構成要素である焦点型コリメータ， 波高分析器, 記録装置, 駆動装置等が主としてこの性能 を左右すると考它られ，本検査法の評価の示標とした， 


\section{1. 使用核種と波高分析器条件の設定}

現在 体外測定には数種類の放射性 同位元素（Radio Isotope 以下 RI）が使用されているが，本法では低エネ ルギ核種に $99 \mathrm{~m}$ Tc $(142 \mathrm{keV})$ ，高ェネルギー核種とし て ${ }^{131} I(364 \mathrm{keV})$ をそれぞれの代表核種として採用する ことにし，他の中ェネルギー，高エネルギー核種は省い た。そしてこれらの核種については波高分析器の level 呿よび window はそれぞれ $142 \mathrm{keV} \pm 10 \% ， 364 \mathrm{keV}$ $\pm 10 \%$ に統一して以下の測定に用いる.

\section{2. 等感度曲線}

この検査法は，シンチスキャナの平面および立体的な 感度分布を知る目的で重要である1) 。特飞焦点型コリ メータや，対向型検出器のコリメータの合成特性につい ては，等感度曲線を知ることが臟器シンチグラム作成の 基本となる。

この検查法には, 点線源の各点移動, 津屋スキャン1), 5),6), コリメータ軸中心線上の感度曲線加らの作図，減 弱曲線より計算で求める方法, フィルムの等濃度曲線よ り求める方法(1),2)， Line source 45 度方向に固定しス キャンを行な5方法等の多数の方法がある，本検査法は， 繁雑で測定に比較的時間を要する久点はあるが，幾何学 的な条件の設定が最も確実な点線源移動法, 和よび最も 普及している津屋スキャン法を採用した。

\section{1 測定方法}

線源は点線源 $10 \mu \mathrm{Ci}$ 前後で，水中と空中で行なう. 点線源移動法, 津屋スキャン法の両法とも線源の移動に は，検出器を固定し線源を移動する方法と，線源安固定 して検出器を移動する方法がある。線源移動の方向は

Fig. 1 亿示した。

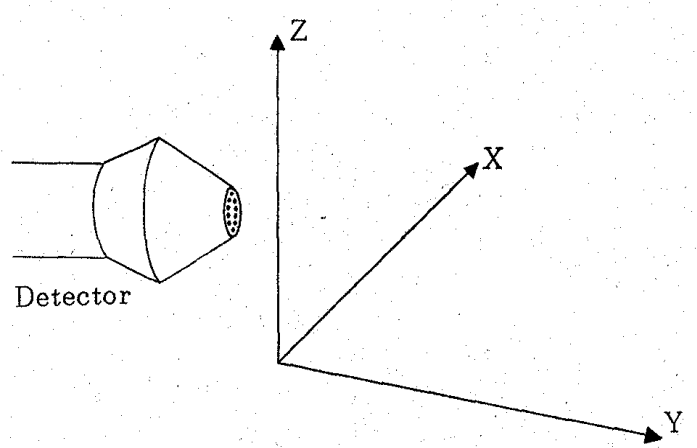

Fig. 1 Out line of source movement for Iso sensitive curve measurment

点線源移動法については上記のどちらの方法でも，各 点に捛ける計数值をスターラーで一定時間（統計变動の 少ない計数值になるまでの時間測定し，最高計数領域を
100\%として 10\% まで計测する (Fig. 1 のX軸方向). 線源と検出器との距離 (Fig. 1 のY軸方向) $1 \mathrm{~cm}$ 間 隔でコリメータの焦点距離の 2 倍末で行ならことが望な しい，線源移動間隔は，X軸（またはZ軸）方向飞 5 ～ $10 \mathrm{~mm}$ 毎の各点に移動すれば充分であるが，焦点型コリ メータの焦点附近では，これより間隔を小さく，1〜2 mm 毎にとる必要がある．Fig. 2 亿作成手順を示した。

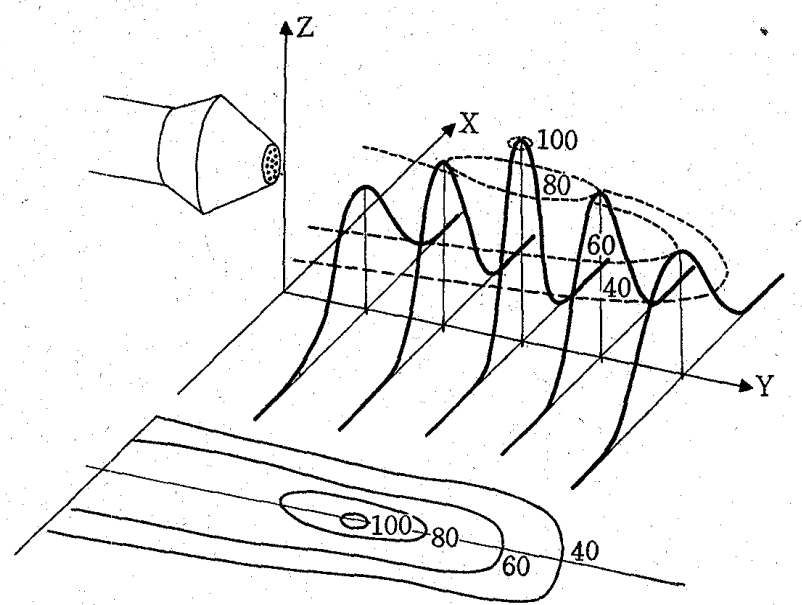

Fig. 2 Measurment technique of Iso sensitive curve

津絪スキャン法の場合は定速移動を行ならが，この際， スキャン速度は，各スキャナの最低スピード，片送りス キャン，時定数はスキャロッピングの発生しない程度等 の各条件設定が重要である。しかし短半減期の線源の使 用については，測定結果を損なわない程度のスピードア ップはやむを得ない。

\section{2 点 線 源}

これ等の測定法では点線源の大ささが問題になる，最 も小さいものは $0.012 \mathrm{inch}^{1}$ （約 $0.3 \mathrm{~mm}$ ）を用いている

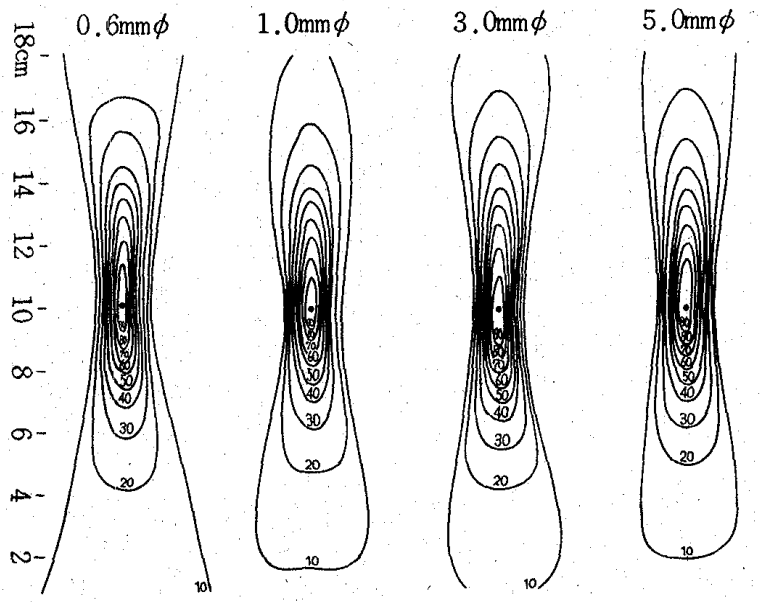

$3210123 \mathrm{~cm}$

Fig. 3 Effect of source type on Iso sensitive curve 
が，各人さまざまの大きさを使用して；その大きさの規 格はいまだにないのが現状である，点線源は小さい程良 いが1)，0.6 mm〜 $5 \mathrm{~mm} \phi$ での実験結果ではもまり大き な差はない（Fig. 3)。本検査法では $2 \mathrm{~mm} \phi$ とした。

$99 \mathrm{~m} \mathrm{Tc}$ 等の短半減期核種の場合は，減衰による計数值 の補正が必要である。

\section{3 測定值と評価方法}

点線源移動による等感度曲線の表示は $10 \%$ ごとに 100 \%から10\%まで表示する、コリメータのサイドシールド まで含めた測定を行ない $0.03 \%$ まで表示している例3 も あるがここの項では10\%までとする。

Fig. 4 に 5 インチ コリメータの，水中での等感度曲

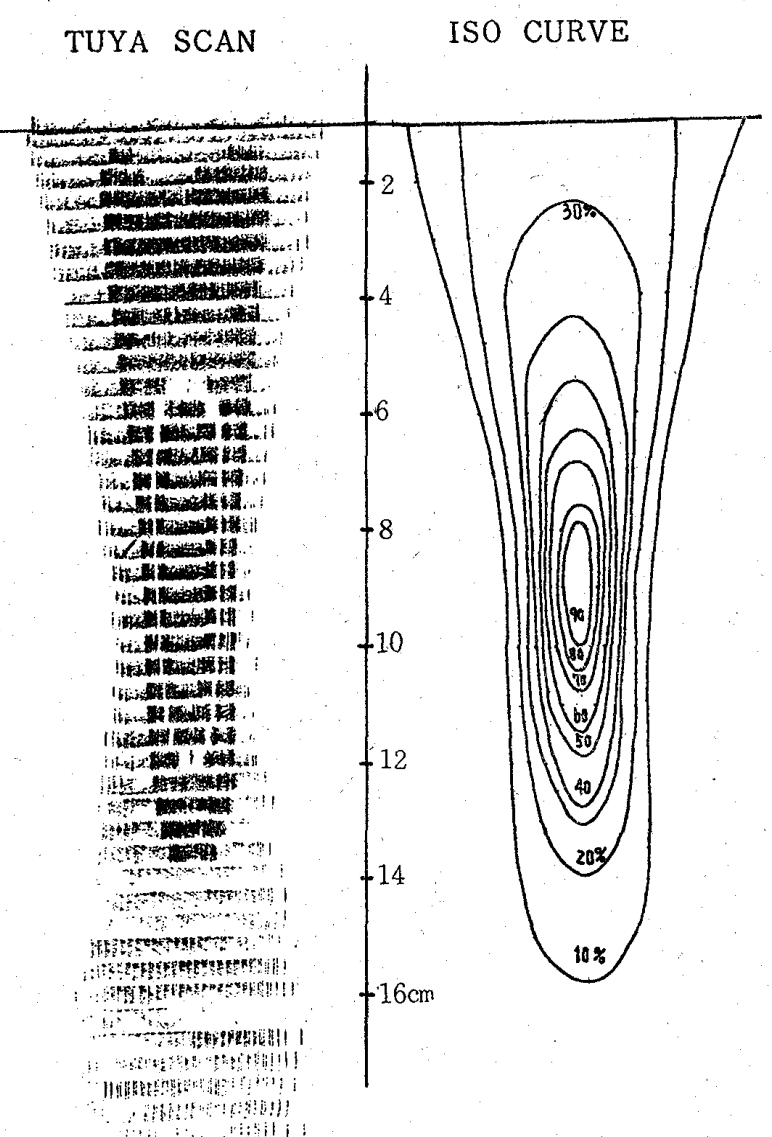

Fig. 4 TUYA scanning and its Iso sensitive curve (in water)

線とカラー打点記録の津屋スキャンを示した。焦点附近 でのレスポンスの幅（X軸上）がせまいもの程分解能が 良く、コリメ一夕軸上（Y軸）でのレスポンスのひろが りは藏器スキャンの際, コリメータの選択に有用である。

\section{3. 波高分析器 (Pulse-Hight-Analyzer)}

波高分析器は目的とする蔵器に集まった RI から検出 器に入る $\gamma$ 線のみを拾い，それ以外に放出される散乱線 を除くのを目的とし，その性能は，得られるシンチグラ
么の画質を左右する。

この波高分析器の性能検査には，エネルギ一分解能， 安定度，エネルギー直線性が孪る。

\section{1 測 定 法}

エネルギー分解能については，Fig.5 のようにして

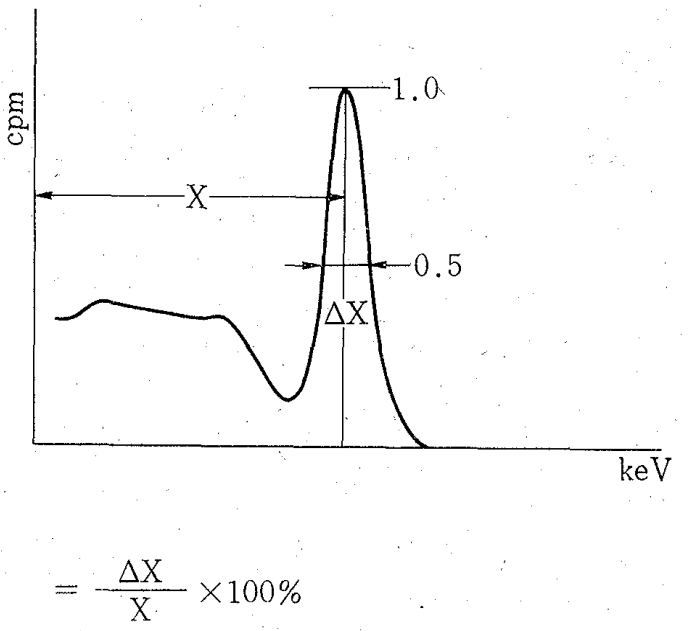

Fig. 5 Outline of energy FWHM measurment

求める ${ }^{97}$ 。この測定には $99 \mathrm{~m} \mathrm{Tc}$ と $131 \mathrm{I}$ を用い，波高分 析器のウィンドウは $10 \%$ 亿設定し める。このときの $\gamma$ 線の光電ピークの半值幅 $\Delta x(\mathrm{~V})$ と， 光電ピークのベースライン值 $x$ (ベースライン電任 $\mathrm{V})$ を求めてェネルギー分解能を求める。

波高分析器の安定度, 即ら，一定のベースライン，ウ インドウ内での $\gamma$ 線の光笔ピークの安定性は，波高分析 器だけでなく，その前段の検出器，プレアンプ，比例增 幅器及び電源電王を含めた安定度が姴求される，徒って， これは 8 時間を目安として，1時間敏に光電ピーク附近 のみのスペクトルをとる方法を用いる，そしてこの光電 ピークををとに波高分析器のベースライン電圧と測定時 間との関係をグラフに示す。

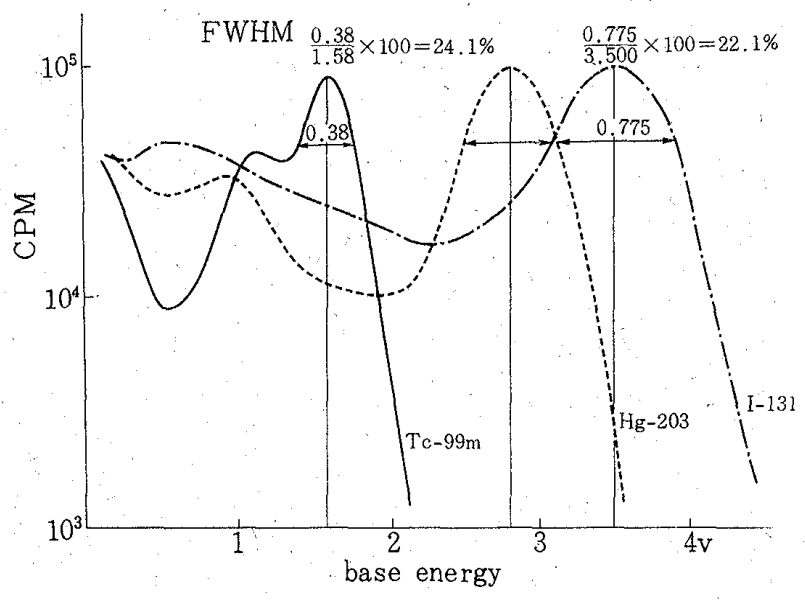

Fig. 6 Tc-99m, I-131 energy FWHM in water 


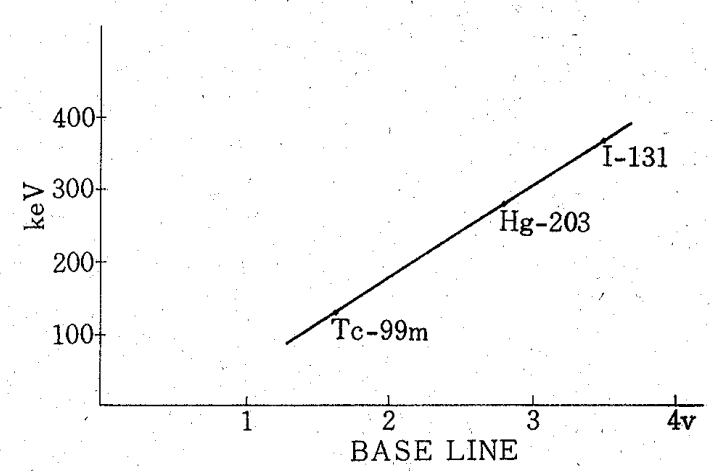

Fig. 7 Linearity of energy response to energy setting

エネルギー直線性は，線源が三核種以上ないと直線の 判定ができないので，この項では一核種以上を追加し，
各光電ピークのベースラィン電压と， $\gamma$ 線のエネルギレ との関係をグラフで示す.

\section{2 測定側と評価方法}

エネルギー分解能は百分率で表示する（Fig. 6 ）。安 定度は; ベースライン電圧と測定時間の関係が直線でめ る必要がある、エネルギー直線性について子同様で, ベ ースライン電圧と $\gamma$ 線エネルギーの関係が直線である必 要がある(Fig. 7)。

\section{4. 感度}

スキャナの感度は, コリメータの性能, 検出器の性能 に依存する，このため投与量や，シンチグラムの画質に 影響を与兄る。この測定法は, 点線源, 線線源, 平面線

Table 1 Sensitivity response of point source, plane source, volume source

\begin{tabular}{|c|c|c|c|c|}
\hline \multirow[b]{2}{*}{ TOSHIBA 5 colli } & \multicolumn{4}{|c|}{ Point source } \\
\hline & activity & count rate & sensitivity & ratio \\
\hline 211 holes & \multirow{4}{*}{$\begin{array}{l}2 \mathrm{~mm} \phi \\
11 \mu \mathrm{ci}\end{array}$} & $3343 \mathrm{cps}$ & $304 \mathrm{cps} / \mu \mathrm{Ci}$ & $100 \%$ \\
\hline 85 & & 1483 & 135 & 44.4 \\
\hline 163 & & 1583 & 144 & 47.4 \\
\hline$\quad 265$ & & 583 & 53 & 17.4 \\
\hline \multicolumn{5}{|c|}{ | Plane source } \\
\hline TOSHIBA $5^{\prime}$ colli & activity & count rate & sensitivity & ratio \\
\hline 211 holes & \multirow{4}{*}{$\begin{array}{c}20 \times 30 \times 1.5 \mathrm{~cm}^{3} \\
12 \mathrm{mci} \\
\\
=2\end{array}$} & $6740 \mathrm{cps}$ & $759 \mathrm{cps} / \mu \mathrm{Ci} / \mathrm{cm}^{2}$ & $100 \%$ \\
\hline 85 & & 2896 & 326 & 43.0 \\
\hline 163 & & 1709 & 192 & 25.3 \\
\hline 265 & & 1005 & 113 & 14.9 \\
\hline \multicolumn{5}{|c|}{ "Volume source } \\
\hline TOSHIBBA $5^{\prime}$ colli & activity & count rate & sensitivity & ratio \\
\hline 211 holes & \multirow{4}{*}{$\begin{array}{c}30 \times 30 \times 20 \mathrm{~cm}^{3} \\
46 \mathrm{mci} \\
=3\end{array}$} & $5460 \mathrm{cps}$ & $2136 \mathrm{cps} / \mu \mathrm{Ci} / \mathrm{cm}^{3}$ & $100 \%$ \\
\hline 85 & & 2507 & 981 & 45.9 \\
\hline 163 & & 1451 & 568 & 26.6 \\
\hline 265 & & 831 & 325 & 15.2 \\
\hline
\end{tabular}

\# 1. $2 \mathrm{~mm} \phi, 11 \mu \mathrm{Ci}$ の線源を点線源とする.

\# 2. $20 \mathrm{~cm} \times 30 \mathrm{~cm} \times 1.5 \mathrm{~cm}$ の面線源を使用

$20 \times 30 \times 1.5=900 \mathrm{~cm}^{3}$

$12 \mathrm{mCi} / 900 \mathrm{~cm}^{3}=13.3 \mu \mathrm{Ci} / \mathrm{cm}^{3}$

$13.3 \mu \mathrm{Ci} / \mathrm{cm}^{3} \div 1.5 \doteqdot 8.88 \mu \mathrm{Ci} / \mathrm{cm}^{2}$

\# 3. $30 \mathrm{~cm} \times 30 \mathrm{~cm} \times 20 \mathrm{~cm}$ の容積線源を使用

$46 \mathrm{mCi} / 18000 \mathrm{~cm}^{3}=2.55 \mu \mathrm{Ci} / \mathrm{cm}^{3}$ 
源，容積線源等によって測定するが，幾何学的条件を同 一にし， $\mathrm{cps} / \mu \mathrm{Ci}$ で評価するのが一般的であるが，測定 条件の設定と，線源の放射能測定精度に問題がある.

\section{1 測定方法}

IEC の草案によると，この測定には $100 \mathrm{~cm}^{2}$ の矩形， 又は円形で，厚さ $5 \mathrm{~mm}$ 以下のルサイト容器を用い，こ れに士 $5 \%$ 以内の精度て測定された線源を入れる。測定 距離は, 焦点型コリメータは, 焦点距離で, 他は $10 \mathrm{~cm}$ の距離としている。

本検查法では線源の作成が簡単で，容積線源法とその 結果がよく一致する平面線源法を採用した，Table 1 は点線源, 平面線源, 容積線源での感度比の比較を行な った. 点線源法は他の二法に比べて信頼度が低い．

平面線源の容器の大きさ中, 円筒状容器 $10 \mathrm{~cm} \phi$ 程度 で，底面の凸凹がなく，各溶液の深さが均等である必要 がある. 溶液の深さは $10 \mathrm{~mm}$ 前後, $100 \mu \mathrm{Ci}$ 前後とし $\pm 5 \%$ 以内の精度とする。

\section{2 測定值と評価方法}

正確には焦点面に抢忷る全有效面積（有效容積）より その中に含まれる $\mu \mathrm{Ci}$ 数を求めて， $\mathrm{cps} / \mu \mathrm{Ci}$ を算出す べさであるが，焦点面に怙ける立体的な全有効面積を求 める事は困難である。そこで便宜上 4.1 の容器に，100 $\mu \mathrm{Ci} / \mathrm{cc}$ の溶液を使用する。この線源を使用して cps/ $\mu \mathrm{Ci} \cdot \mathrm{cc}$ を感度として定義することにした。

結果的には容積線源による感度表示であるが溶液層の 厚さが臨床測定条件に比較して薄いために平面線源法と 名付け $\mathrm{cps} / \mu \mathrm{Ci} \cdot \mathrm{cm}^{2}$ で表示することにした。

\section{5. 計数率特性}

計数率特性は，一般には高計数率の場合に問題となる。 使用さるシンチスキャナの測定系に执いて，測定器の計 测する計数率と，測定系内に入ってくる真の計数率との 関係を知るために必要な性能検査法の一つである，一般 に数え落し，分解時間で表現されるが，各計数率レベル でぞの程度の数え落しがあるかを知って括く必要がある。 但しシンチグラムでは，打点方式，カラー打点方式，写 真記録方式等の記録方法では計数率に対する追随性が悪 いので，別の力法による評価が必要である。

分解時間の測定には，二線源法9， シンクロスコープ によるパルス幅の計測9)，短半減期核種を用いた減衰曲 線からの測定 ${ }^{9}$ ， 線源増加法 ${ }^{16)}{ }^{18}$ )， 距離の逆二乗則の 利用法等が女る。

\section{1 測定方法}

本検査法では二線源法と，線源增加法を採用する。

二線源法は次式上り求める。

$$
\begin{aligned}
& \text { 線源 (1) の計数值 } n_{1} \\
& \text { 線源 (2) の計数值 } \quad n_{2} \\
& \tau=\frac{n_{1}+n_{2}+n_{12}-n_{b}}{n_{12}{ }^{2}-n_{1}^{2}-n_{2}{ }^{2}} \quad \text { 線源 (1) }+ \text { (2) の計数值 } n_{12} \\
& \text { 自然計数率 } n_{b} \\
& \text { 分解時間 } \tau\left(\mu_{\mathrm{sec}}\right)
\end{aligned}
$$

この検查法では $n_{1}+n_{2} \cdot$ と $n_{12}+n_{b}$ は計数值が近い值 になるため分解時間を 正確に測定するためには $n_{1}, n_{2}$, $n_{12}, n_{b}$ の值が統計変動の少ない值でな恀机ばならない。

一般にはコリメータなしで， $n_{1} ， n_{2}$ は $2 \times 10^{4} \mathrm{cpm}$ くら (数学るような線源が必要で 9$), n_{1}, n_{2}, n_{12}$ は $10^{6}$ カウ ント以上が望ましい。

線源増加法は，コリメータなしで，クリスタル面より $20 \mathrm{~cm}$ 前後の一定距離汇線源を置き，そのキューリ值に 対する計数值を測定する。線源は順次增加し同一条件で 測定する．剆定值は横軸にキューリ数, 縦軸に計数值を とった座標にプロットし，この特性曲線を作る(Fig. 8).

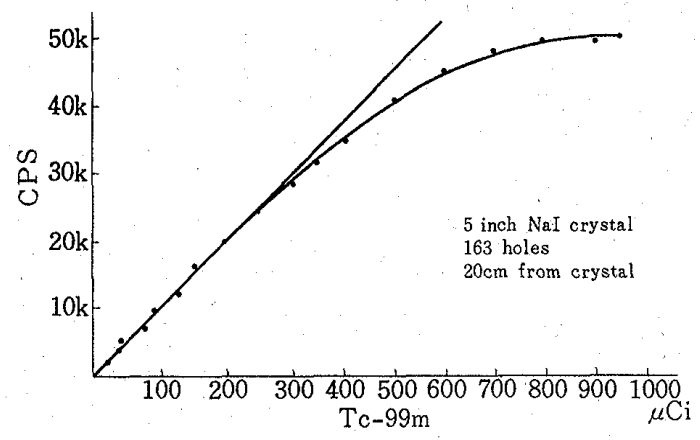

Fig. 8 Characteristic curve of counting rate

この曲線より，各設定条件汁応じて連続的な分解時間 と，計数率との関係を求めることがでさる.

この計数率特性より分解時間を求めるためには，低計 数率領域からの外插によって真の值を定め，特性曲線上 の実測值から次式で分解時間を算出する。

$$
N=\frac{n}{1-n \tau} \quad\left\{\begin{array}{l}
\text { 真の計算值 } \\
\text { 実 測 值 } \\
\text { 分解時間 }
\end{array}\right.
$$

\section{2 測定值と評価法}

分解時間は前述のごとく $\mu \mathrm{sec}$ で表示する，計数摔特 性の場合，IEC の草案ではコリメータなしで，真の計

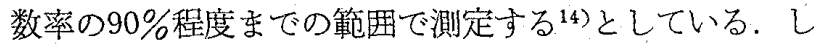
かしこれはシンチグラムの撮影条件とも関連するのでス キャナの使用可能と考学られる範囲までは知って抹く必 要があると思われる。

\section{6. 総合分解能}

周知の上うにスキャナはスキャンすることによって， シンチグラムが得られるため，コリメータから display 
装置までの，全ての系についての分解能を知る必要があ り，ここでは総合分解能が使用される。

この検査法にはテストパターン法（鉛バーブォントム

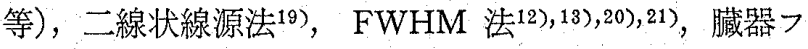

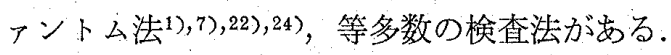

\section{1 測 定 法}

本検查法では，テストパターン法（バーファントム， スターファントム, 各種の臟器ファントム), 線状線源 法, FWHM 法を採用する。

テストパターン法には，ファントム内に直接 RI を封

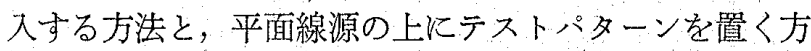
法がある。テストパターンの模様は，直線状の数種の格 子を並ベたバーフォントム22, 30),31)，スターフォントム， 円孔の直径の大きさの異なるもの等があるが，テストす るシンチスキャナの分解能を考慮して格子間隔; 门孔の 淔径等を選択寸る。

蔵器フォントム法は, IAEA 肝スライスファントム, 甲状腺フォントム等があるが，人体模型中に臟器フォン トムを装着して，その中にホット又はコールド線源を入 れて，その判別能を比較する方法が滛床条件とシュミレ ーションできる点で優れている.

いずれの方法も使用 $\mathrm{RI}$ は $300 \mu \mathrm{Ci}$ 前後で， スキャ ン速度は最低スピードが望ましいが，各装置ともに異な ることと，99m Tc の短半減期核種を考虑し，咟床条件に 適した速度を考光合わせると $60 \sim 90 \mathrm{~cm} / \mathrm{min}$ 前後が良い， シンチグラム設定条件は，打点記録の場合，適度の二 ントラスト強調で, カットオフはバックグラウンド程度 とし，写真記録の条件は，最高濃度部が1.5〜1.7程度と する。

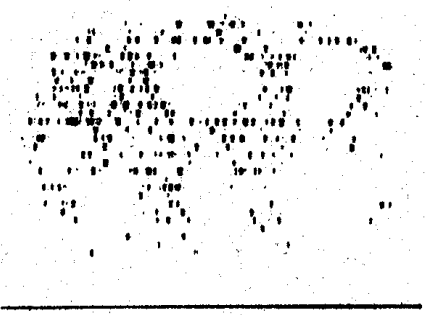

$D=0.4$

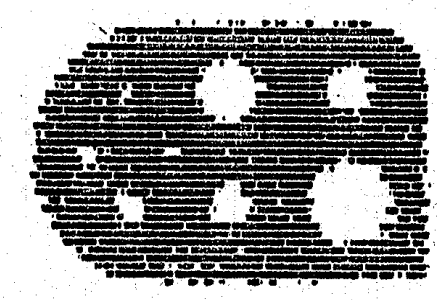

$D=1.4$
FWHM 法は Line source を用い，内径 $2 \mathrm{~mm}$, 長さ $15 \mathrm{~cm}$ 以上で，最大計数值が $10^{5}$ カウントになるよ 5 に $100 \mu \mathrm{Ci}$ 前後学封入する. 記録はマルチチャンネルアナ ライザ，又はペンレコーダを用いる，線源の移動は，各 スキャナの最低スピードを用いる。吸収体は水又はアク リル等とし，コリメータ表面から吸収体までの Air gap は $2 \mathrm{~cm}$ 以下とする. 線源移動幅は，X軸方向に $30 \mathrm{~cm}$, 深さY軸方向に $20 \mathrm{~cm}$ までとする。この際，スキャン開 始から $5 \mathrm{~cm}$ を通過後上り記録を開始する。このため補 助スキャンを含めると，スキャン範囲は $35 \mathrm{~cm}$ となる。

アナライザ，ペンレコーダが使用できない場合は，等 感度曲線の各点移動方式によりスケーラーを利用して計 数值を読み取り，Line Spread Function (LSF) を求め る方法もある。

二線状線源法は，FWHM 法の Line source 2 本を用 い，測定はンリメータの焦点距離で行ない，記録はFW HM 法に準ずる. 2 本の Line source は密着位置より 1 〜 mm 毎にその間隔を広げ，得られる曲線がダブルピ ークになる直前の間隔で，その分解能を判定する.

\section{2 測定側と評価法}

ファントム法は，観察者の視覚的判定による.テスト パターン法はバーフォントムの格子の解像限界を $\mathrm{mm}$ 表示し，円板又は球で，その直径を $\mathrm{mm}$ 又は $\mathrm{cm}$ で表 示する. 本検査法は, 打点記録, 写真記録等の記録の条 件設定がこの結果を左右する，各シンチグシム共，最適 浱度で撮る必要がある。

写真記録の濃度については， IAEAの肝スライスフォ ントムの実験では最高濃度部で 1.4 が最適濃度であった (Fig. 9). 前 RI 専門委員会の “シンチグラム記録表示

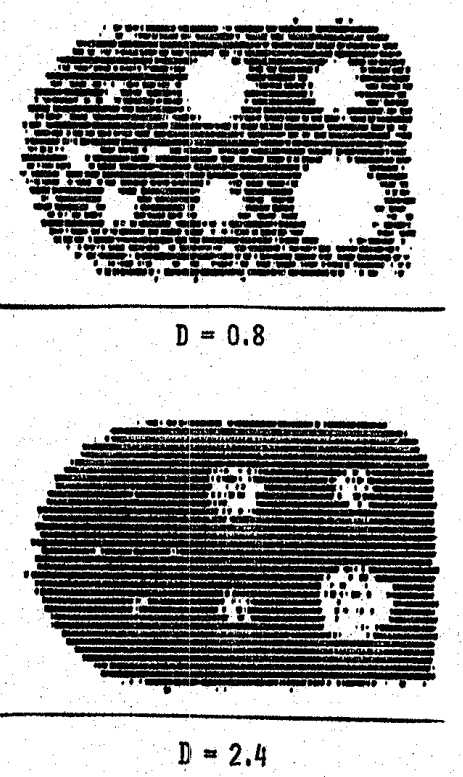

Fig. 9 Density effect of IAEA liver slice phantom photogram 


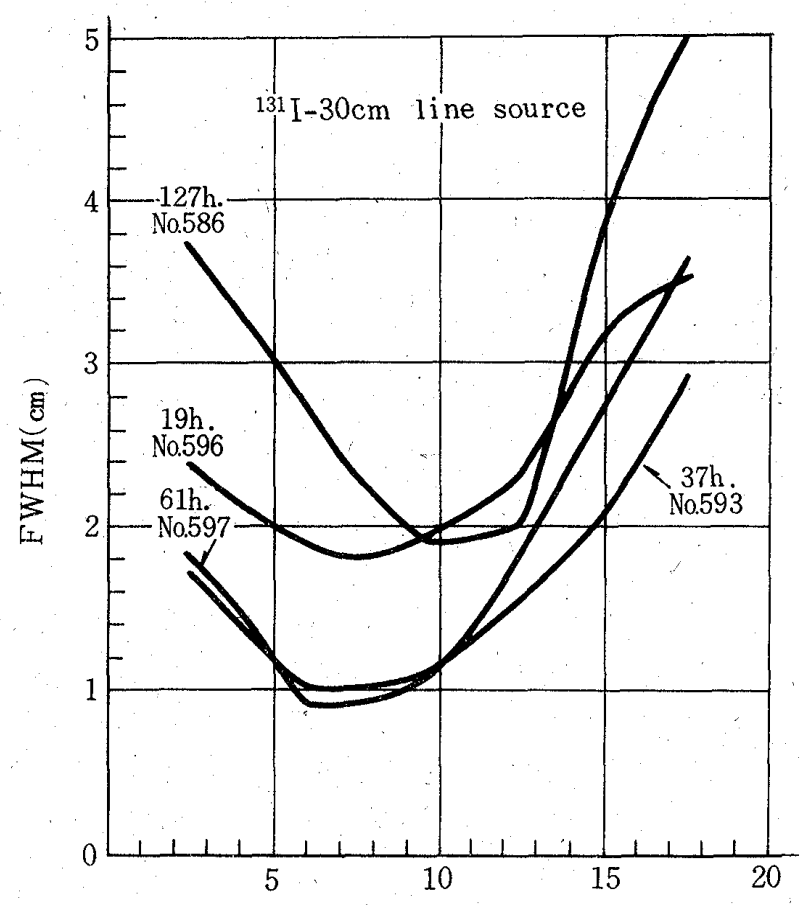

Source to collimator distance $(\mathrm{cm})$

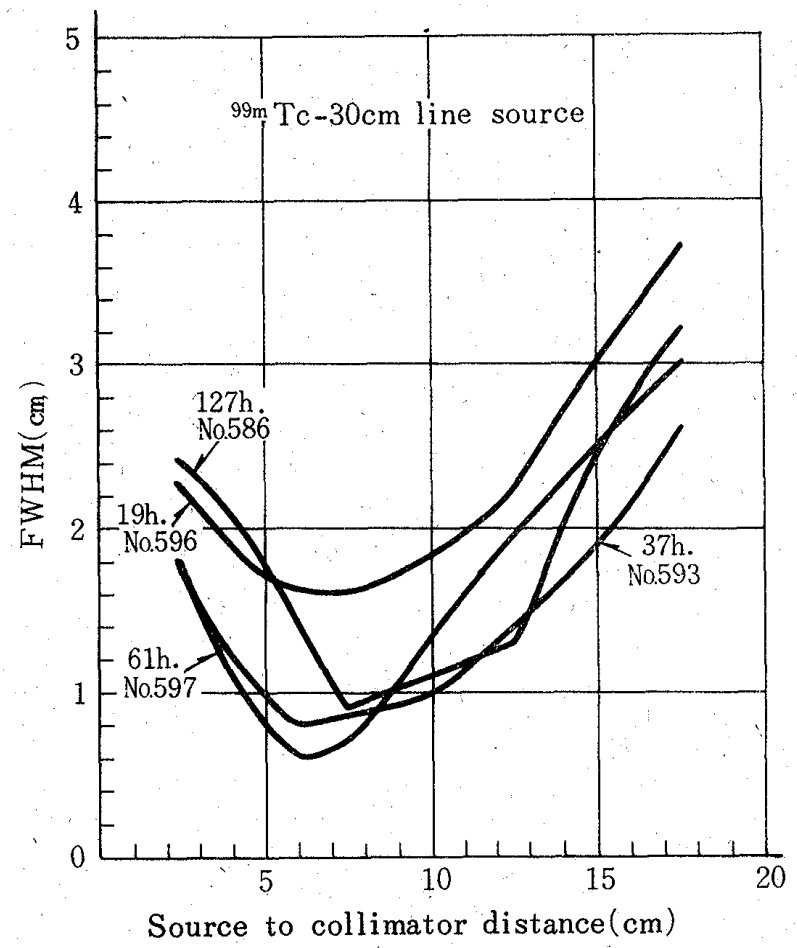

Source to collimator distance $(\mathrm{cm})$

Fig. 10 Spatial resolution (FWHM) of four N.C collimator as a function of source to collmator distance for I-131 and Tc-99m

の標準化”で，容積線源のシンチグラフィーの最適濃度 最高值は $1.5 \sim 1.7$ と結論している ${ }^{22)}$.

FWHM 面功の距離の関数として表示する（Fig. 10).

MTF を求める場合，FWHM 学求めた LSF を $F(x)$ と和くと MTF $H(\omega)$ 性，

$$
H(\omega)=\frac{\int_{-\infty}^{\infty} F(x) e^{-2 \pi i \omega} d x}{\int_{-\infty}^{\infty} F(x) d x}
$$

で与えられる20),23),27)。表示はレスポンスと lines/cmの 関数で表示する。

二線源法はダブルピークが判別できる限界の二線源間 の距離を mm で表示する。

\section{7. バックグラウンド計数と遮蔽能}

バックグランド值の測定は，測定装圆の感度，測定装 置の RI 污染のチェック，周辺の污染のチェック，検出 器の遮蔽能チェック等が女り，これ等は装置の使用開始 前にデータを記録すべきである．いろいろな方向に検出 器を向けて使用する場合は，方向依存性もチェックする 必要がある。

\section{1 測 定 法}

本検査法では，各エネルギーごと，各ウィンドウ幅ご とのバックグラッンド測定と, 検出器の遮蔽能を採用し た。
エネルギー別によるバックグラウンド值の測定は，コ リメータ装着で，波高分析器のウィンドウ幅は $10 \%$ に設 定し， $50 \mathrm{keV} よ り 400 \mathrm{keV}$ 前後まで $50 \mathrm{keV} こ ゙ と の$ 計 数値を計測して計数率とェネルギーの関係で表示する (Fig. 11). 测定時間は10 分前後とするが，できる限り 長時間測定が望なしい。

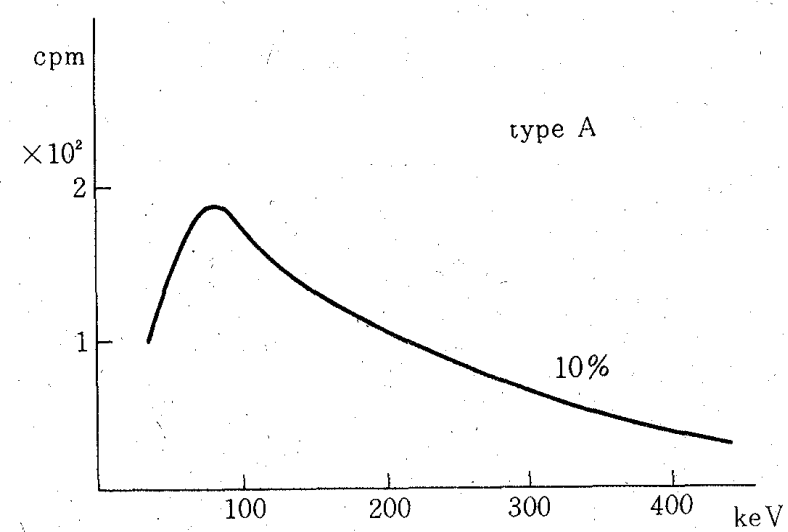

Fig. 11 Background value of each energy setting (type A)

各ウィンドウ幅ごとのバックグランド測定はウィンド ウ幅を，5，10，20，30 各\%ごとに変化させ，他は上記 と同様である。Fig. 12 に例をあげた。

遮蔽能は，等感度曲線と同じ点線源を用い，測定条件 は点線源移動法と同じである，測定には，コリメータ装 着状態で点線源を検出器の外壁表面に密着して，各点の 


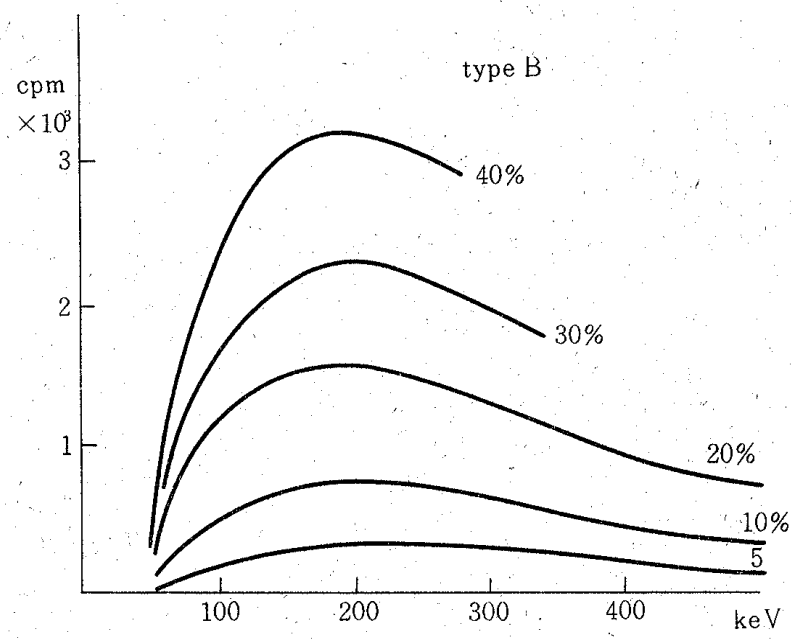

Fig. 12 Background value of each energy and window width (type B)

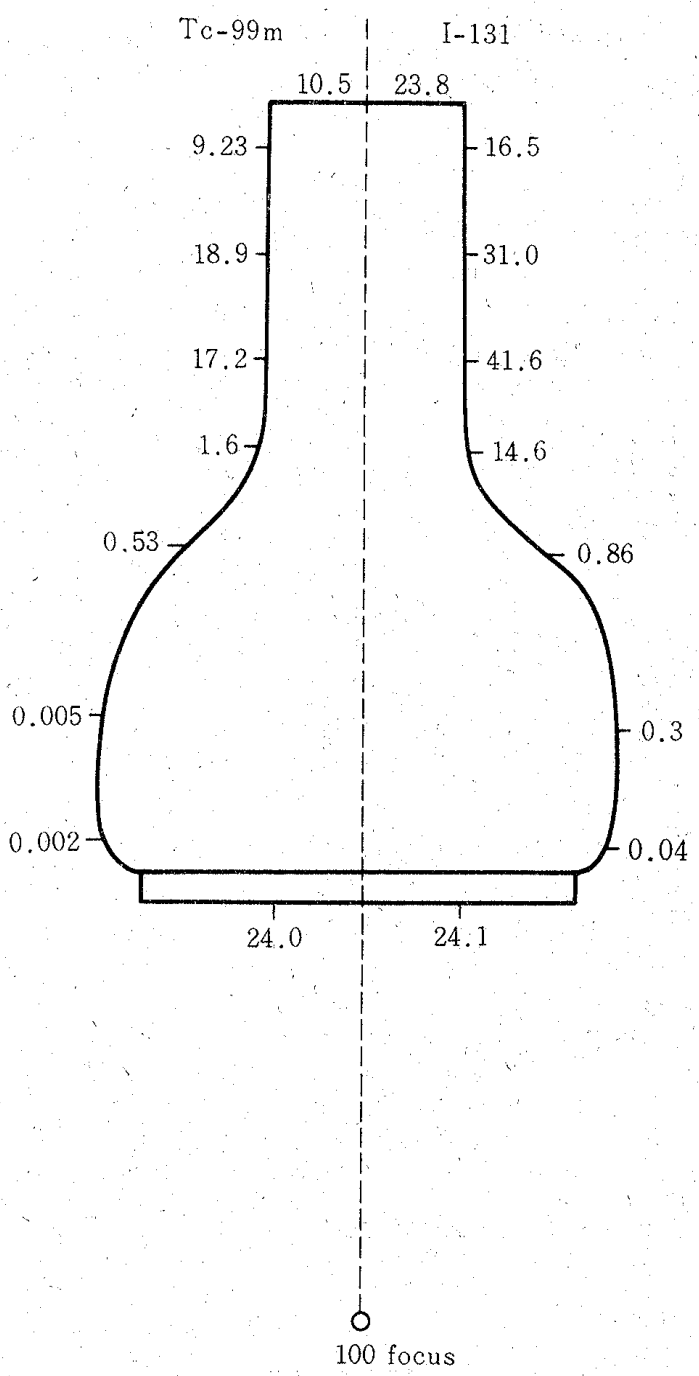

Fig. 13 Shielding efficiency of detector for $T c-99 \mathrm{~m}$ and I-131

計数值を計測する。これとコリメータ焦点での計数值を 求め，この值を $100 \%$ とて各点の計数值を\%表示する.
Fig. 13 にその一例をあげた.

\section{2 測定值と評価法}

各結果の表示については Fig. 12〜13 た示したが，コ リメータによってはサイドシールドが異なるるのもある ので28，使用コリメータごとにデータをとろ觉ることが 必要である。

遮蔽能については，Fig. 13 にあげた例にみられるよ

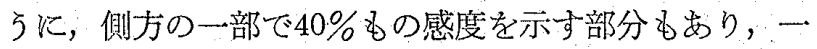
度は検討を行な与検查法である。

\section{8. 信号と記録の応答特性}

電気的な信号怔正確に応答しても；シソチグラムの記 録方法，特汇機械的な記録方法 (カラー記録, 打点記録) 隹号の遅れによる愦記録を生ずる可能性が女る。

この性能検査には，打点記録の場合は，スキャン速度， 時定数，計数率等がある，写真記録の場合は，発光時間 とシンチグラム，計数率一濃度特性等の検查項目がある。 これ等は得られるシンチグラムの像のゆがみに影響する 上で重要で㚣る。

\section{1 測 定 法}

本㭘查法では，スキャン速度，時定数，計数率，レー トダウソ，部数率一濃度特性, 発光時間とシンチグラム。 について検討する。

測定は，Line source をスキャンし，上の各条件を变 化して得られるシンチグラムが，西線に再現される条件 の範团を検討する，使用する線源は，6.1 の FWHM 法 の Line source を用いる.

スキャン速度がパラメータの場合は，時定数は最子短 か心值を設定する。速度は，Table 2 のよに各社の スキャン速度が同一でないので，最低速度と，50，100， $200,300,400 \mathrm{~cm} / \mathrm{min}$ 各前後を目安にスキャンする. スキャン力向は，片送りと，往復送りの両方行なら、不 キャン回数性少なくと本 6 回 (6.例) 以上.

時定数がパラメータの場合は，上記のスピードと時定 数のダブルパラメータになる，時定数もまた，最短時定

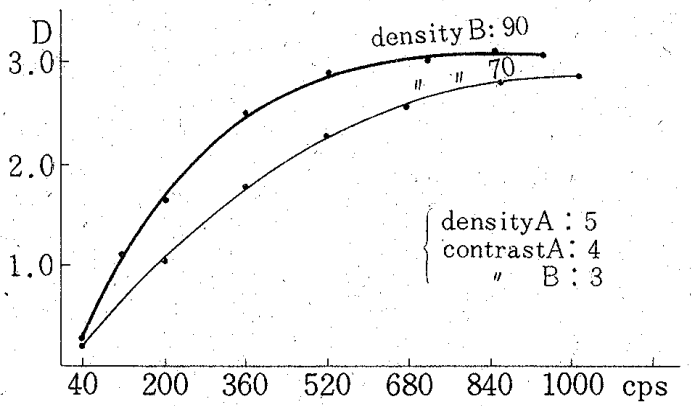

Fig. 14 Density response to counting rate 
Table 2 Setting scale of scanning speed and time constant in each appratus

\begin{tabular}{|c|c|c|}
\hline$x-$ - - 名 & Scanning speed & Ratemeter time constant \\
\hline $\begin{array}{l}\text { Toshiba } \\
\text { ユニバーサル RDT } 201\end{array}$ & $20 \sim 240 \mathrm{~cm} / \mathrm{min}$ & $\begin{array}{l}0.03,0.1,0.3,1.0 \\
3.0 \mathrm{sec}\end{array}$ \\
\hline Shimazu & $20 \sim 200$ & $0.1,1,2,5,10$ \\
\hline $\begin{array}{l}\text { Nuclear Chicago } \\
\text { pho/Dot II }\end{array}$ & 30 & $\begin{array}{l}0.02,0.2,0.4,0.8, \\
5\end{array}$ \\
\hline $\begin{array}{l}\text { Aloka } \\
\text { マルチモードスキャナ }\end{array}$ & $26 \sim 600$ & 0.1 \\
\hline $\begin{array}{l}\text { Aloka } \\
\text { JSS-133 U }\end{array}$ & $20 \sim 200$ & \\
\hline $\begin{array}{l}\text { Aloka } \\
\text { JSS-153 U }\end{array}$ & $50 \sim 500$ & \\
\hline Hitachi & $5 \sim 500$ & $\begin{array}{l}0.005,0.01,0.02, \\
0.05,0.1,0.2,1,5, \\
20\end{array}$ \\
\hline $\begin{array}{l}\text { Simens } \\
\text { シンチマート }\end{array}$ & $12 \sim 180$ & \\
\hline Abbott & $10 \sim 750$ & \\
\hline Elscint & $\sim 500$ & $\begin{array}{l}0.01,0.03,0.1,0.3 \\
1,3,10,30\end{array}$ \\
\hline
\end{tabular}

数, $0.01,0.05,1,5,10$ 各 $\sec$ と最長時定数の各前後 奔目安にする。

写真記録の場合は，上の二つに，発光時間が加わる。 これは各社独自の機構をとり入れているので，值の提示 はできないが，最低から最高まで，6〜 7 段階程度を選 んだ皃らがよいと考える。さらに写真記録の場合は，言十 数率と濃度の関係がある。この測定は，パルスジェネレ 一夕を用いる方法が良いが，簡単な方法としては；強さ の異なる RI を適当に配列してスキャンする方法でも间 能である。いずれにせよ cps と濃度との関係をグラフ表 示する (Fig. 14).

\section{2 測定值と評価法}

Line source のスキャン法による信号と記録の反応特 性の測定結果は，シンチグラムの直線のみだれを視覚に よって判定する。各パラメータとも，その Line source のシンチグラムのゆがみの限界を知ることが最終目的で ある、前述のごとく，各社各様で自慢の機構を持つため， 各項目のパラメータを決めるのはむずかしい。このため 本検査法では上に述べた值に，各施設で行なわれている 臨東条件のパラメータが含まれることを望みたい。

また，写真記録の濃度曲線については，最近は最高計 数值で濃度の条件設定が決まる自動機構型スキャナが出
現して，この項目は不要の場合があるか知れないが， この際は取捨選択を和願いしたい.

\section{9. 焦点型コリメータ}

焦点型コリメータの性能は，シンチグラムの画質に最 も大きな影響を与えるので，その取扱いには注意を要す る.

コリメータ固有の分解能，感度等は同一型式のコリメ ータでも相違があるので，まず目視による孔の大ささ， むら，変形，きず等を最初にチェックする。

その他，コリメータの検査法については，多くの方法 が提唱されているがロ 8)，本検查法では，コリメータ自 体の性能検查を目的とする。

本検查法では，幾何学的梌価方法による分解能，感度， 焦点距離等を推定する。また，隔壁間の遮蔽能を測定す るために，Septum-penétrationの性能検查法を採用する。

\section{1 計算方}

幾何学的評価法については，Hine の提唱している方 法を採用する12),13),20),28).

焦点距離 $(F)=\frac{d_{1} \cdot L}{d_{0}-d_{1}}$

幾何学的分解能 $(R)=\frac{d_{0} \cdot d_{1}}{d_{0}-\bar{d}_{1}}=d_{0} \frac{F}{L}$ 
感度 $(S)=\frac{\pi N d_{0}^{2} d_{1}^{2}}{8\left(8 L^{2}\right)} \cdot \eta \cdot p \cdot 2.22 \times 10^{6}$

$\mathrm{cpm} /\left(\mu \mathrm{Ci} / \mathrm{cm}^{2}\right)$

穴の淔径 $d_{0}, d_{1}$

穴の間隔 $S_{0}, S_{1}$

$\begin{array}{ll}\text { 穴の平均間隔 } & h \\ \text { 穴の数 } & N \\ r \text { 線の数 } / \text { 崩壊 } & \eta \\ \text { 検出效率 } & p\end{array}$

$p$ は Fig. 15 より求める。

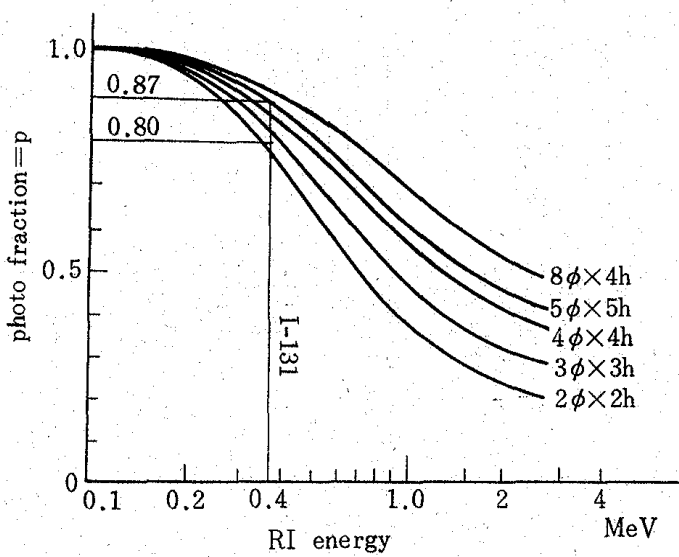

Fig. 15 Photo fraction of RI energy for NaI crystals of five types

Septumpenetration はコリメータの隔壁および側壁の $\gamma$ 線透過に上る分解能の低下を検查する方法である．線 源と方法は，2.1 の点線源移動法と同じである。但し測 定距離は，コリメータ焦点距離で行なう．

\section{2 評価 方 法}

幾何学的評価法は, $d_{0}, d_{1}, S_{0}, S_{1}, h, L, R$ は $\mathrm{cm}$, $N$ は個数， $S$ は $\mathrm{cpm} / \mu \mathrm{Ci} / \mathrm{cm}^{2}$ で表わす。この方法は RI を一切使用しないため，線源の大きさ， $\mathrm{Ci}$ 数の規定 が不要である利点がある。しかしこの方法は高エネルギ - $\gamma$ 線に対する Septum penetration 効果を考慮してい
ないため，低エネルギー核種に対しては，值の信頼度は 高いが，高エネルギー核種に対しては， $S Ｒ$ ともに信 頼度は低(28),29). Table 3 K, 幾何学的評価法と line source 法での結果を比較した.

Septum penetrationは, 低エネルギー核種と高エネル ギー核種の、コリメータ焦点で得られる．Point source response で表わされる，例を Fig. 16 に示した．本検 查法では， $99 \mathrm{~m} \mathrm{Tc} ， 131 \mathrm{I}$ の二核種に限定して女るが，当 検查法は臨床で使用される他の核種についてる検討する ことが望ましい。

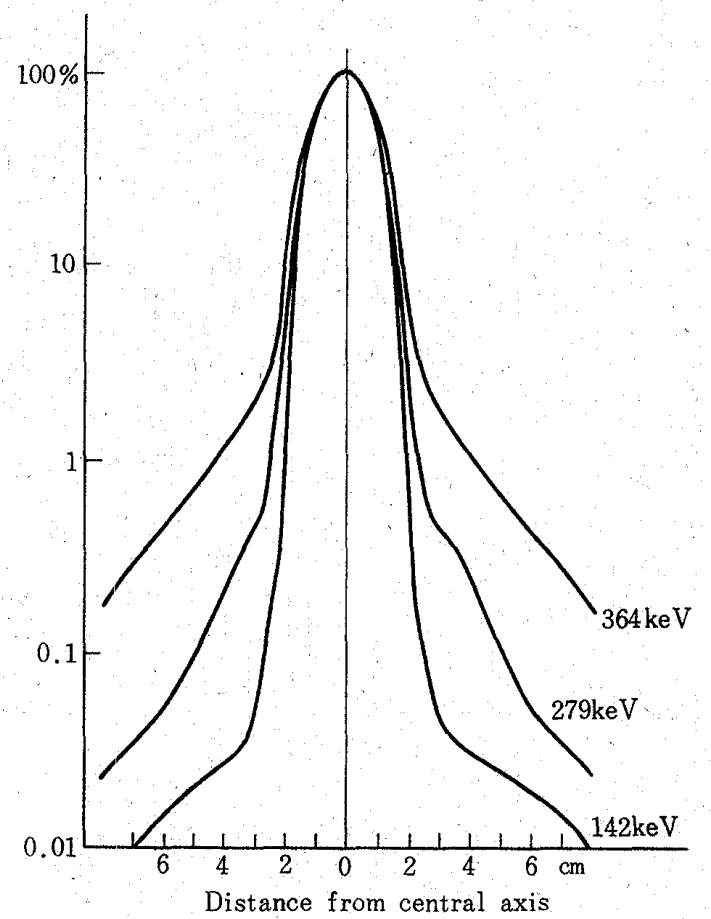

Fig. 16 Septum penetration of N:C (3 inch) 19 hole collimator to three RI energy

Table 3 Comparison of evaluation on geometrical method and others

\begin{tabular}{|c|c|c|c|c|c|c|c|c|c|c|c|}
\hline \multirow{3}{*}{$\begin{array}{l}\text { Collimator } \\
\text { Toshiba (5 in.) }\end{array}$} & \multicolumn{5}{|c|}{ Geometrical method } & \multicolumn{2}{|c|}{$\begin{array}{l}\text { FWHM } \\
\text { (in water) }\end{array}$} & \multicolumn{2}{|c|}{$\begin{array}{l}\text { Depth of best } \\
\text { resolution }\end{array}$} & \multicolumn{2}{|c|}{$\begin{array}{c}\text { Sensitivity } \\
\text { (volume source) }\end{array}$} \\
\hline & \multirow{2}{*}{$\frac{\mathrm{R}}{\mathrm{cm}}$} & \multirow{2}{*}{$\frac{\mathrm{F}}{\mathrm{cm}}$} & \multicolumn{3}{|c|}{$\mathrm{S}$} & \multirow{2}{*}{$\frac{\mathrm{I}-131}{\mathrm{~cm}}$} & \multirow{2}{*}{$\frac{\text { Tc-99m }}{\mathrm{cm}}$} & \multirow{2}{*}{$\frac{\mathrm{I}-131}{\mathrm{~cm}}$} & \multirow{2}{*}{ Tc-99m } & \multirow{2}{*}{$\frac{\mathrm{I}-131}{\%}$} & \multirow{2}{*}{$\frac{\mathrm{Tc}-99 \mathrm{~m}}{\%}$} \\
\hline & & & $\mathrm{cpm} /$. & $\left(\mu \mathrm{Ci} / \mathrm{cm}^{2}\right)$ & $\%$ & & & & & & \\
\hline No. $85-11$ & 0.9 & 10.0 & & 10395 & 42 & 0.9 & 0.8 & 10 & 10 & 64 & 21 \\
\hline No. $163-10$ & 0.55 & 8.6 & & 4644 & 19 & 0.6 & 0.5 & 9 & 9 & 40 & 12 \\
\hline No. $265-15$ & 0.65 & 12.5 & & 2401 & 10 & 0.7 & 0.5 & 13.5 & 14 & 24 & 7 \\
\hline \multicolumn{12}{|c|}{ Nuclear Chicago ( 3 in.) } \\
\hline No. 596 & 2.0 & 12.0 & & 24581 & 100 & 1.8 & 1.6 & 7.5 & 7.5 & 100 & 100 \\
\hline No. 593 & 0.9 & 8.7 & & 4187 & 17 & 1.0 & 0.8 & $6-7.5$ & 6 & 18 & 19 \\
\hline No. 597 & 0.6 & 6.4 & & 3434 & 14 & 0.9 & 0.6 & $6-7.5$ & 6 & 17 & 13 \\
\hline No. 586 & 1.0 & 9.4 & & 9772 & 40 & 1.9 & 0.9 & 10 & 7.5 & 306 & 58 \\
\hline
\end{tabular}




\section{0．スキャン速度}

スキャナの走查速度は, $10 \mathrm{~cm} / \mathrm{min}$ 程度から $700 \mathrm{~cm} /$ minのものおである (Table 2). その速度は, 連続可変, ステップ式で，いずれもサーボ式の速度制御電動機が用 いられ，定速性が保たれている：本検查法では，この定 速性, メ一カ仕様の速度との比較拈よび走査の蛇行, ピ ッチをらを測定する。

\section{1 測定方法}

定速性の検査法は，位監の信号を出せるスキャナにつ いては，XY レコーダ又はペンレコーダを用いて，定速 性を調べる。

仕様速度には，ストップウォッチを用いる。これは， スキャンスタートより $5 \mathrm{~cm}$ から時間測定を開始し，走 查距離 $30 \mathrm{~cm}$ での時間で決める.

蛇行，ピッチむらの測定は，パルスジェネレータを用 い，一定のパルスを波高分析器に入力し，これをも之に， シンチグラム势撮る。 または平面線源をスキャンする。. スキャン面積は $10 \mathrm{~cm} \times 10 \mathrm{~cm}$ 以上とする.

以上の測定は片送りと往復スキャンについて行ない， スキャン速度は8.1を目安に行なう。

\section{2 測定值と評価法}

定速性は時間と位置信号の関係で示す，定速が保たれ ている場合は淔線となり，速度が定速でないと，直線と はならない。

スキャナの各速度についての測定は，メーカ仕様より 若干のずれがある場合も㚣り，交た使用頻度によっても 変化することがあるので，実測㒹が大切である。
スキャン時の蛇行とピッチむらは（Fig. $17 \mathrm{~A} ， \mathbf{B}$ )， 1 回のスキャンで得られる打点列からのはみ出し分の平 均值を $\mathrm{mm}$ で表少す。
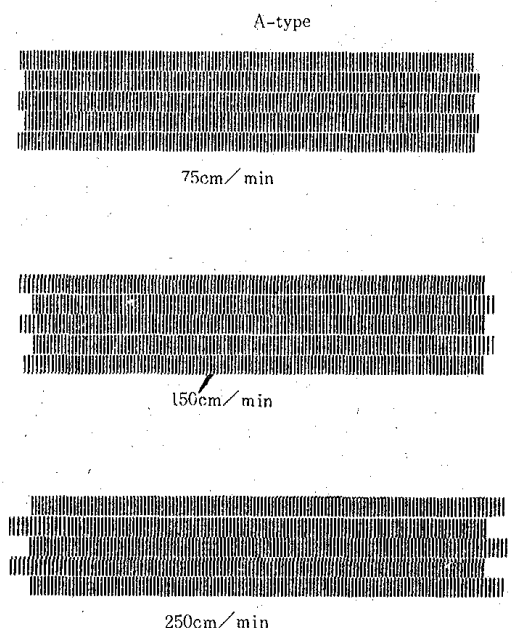

A : new appratus

B-type
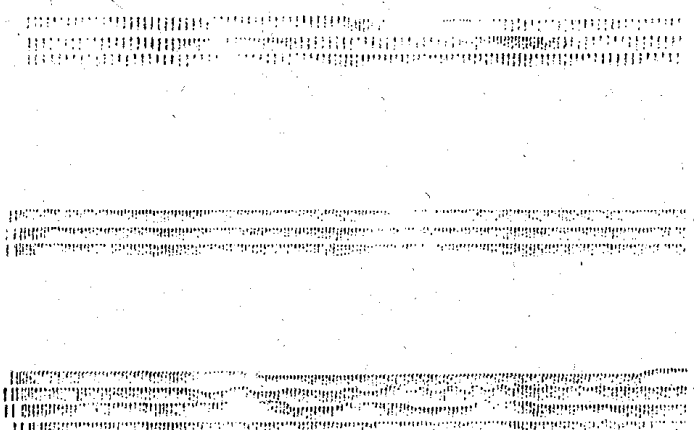

$B$ : old appratus

Fig. 17 Image distortion for each scanning speed

\section{II. シンチカメラの性能検査法}

\section{1. 使用核種と波高分析器条件の設定}

使用核種としては $99 \mathrm{~m} \mathrm{~m} \mathrm{c}$ 定使用し，ウインド幅は 142 $\mathrm{keV} \pm 10 \%(127 \mathrm{keV} \sim 156 \mathrm{keV})$ に設定する，但し高エ ネルギーコリメータ使用の場合は， ${ }^{131}$ 艺使用し， 364 $\mathrm{keV} \pm 10 \% （ 328 \mathrm{keV} \sim 400 \mathrm{keV})$ にて測定を行う.

\section{2. 等感度曲線}

シンチカメラの平面及び深さ方向の感度分布を立体的 にとらえるため等感度曲線は重要である。特にシンチカ メラは低ェネルギー核種の利用が大半を占めるため樑さ 方向のンスポンスを知ることは踟床款断上重要である。

\section{1 使用材料および作成方法}

$2 \mathrm{~mm} \phi$ 程度の球または円筒状の点線源を作成する。 放射能は $1 \mathrm{mCi}$ 前後とし，水槽または水等価物質フォ ントム中での感度分布を測定する。

\section{2 測定方法}

この測定にはポイントソースの各点移動，中心線上の 感度曲線より作図で求める方法，減弱曲線より計算で求 める方法等が岕るが，本検查方法でばポイントソースの 各点移動法を採用する．この方法は測定点が非常に多い ため，測定に長時間要要する久点がある，幾何学的な設 定条件を正確にすれば，まる程度内揮法により，測定点 を少なくすることができる。等感度曲線は $100 \%$ から10 
\%まで測定すれば十分である．各測定点は統計変動の少 ない值で測定する.

\section{3 測定結果および評価方法}

Fig. 18 はポイントソースの各点移動法により求めた ISO RESPONS CURVE

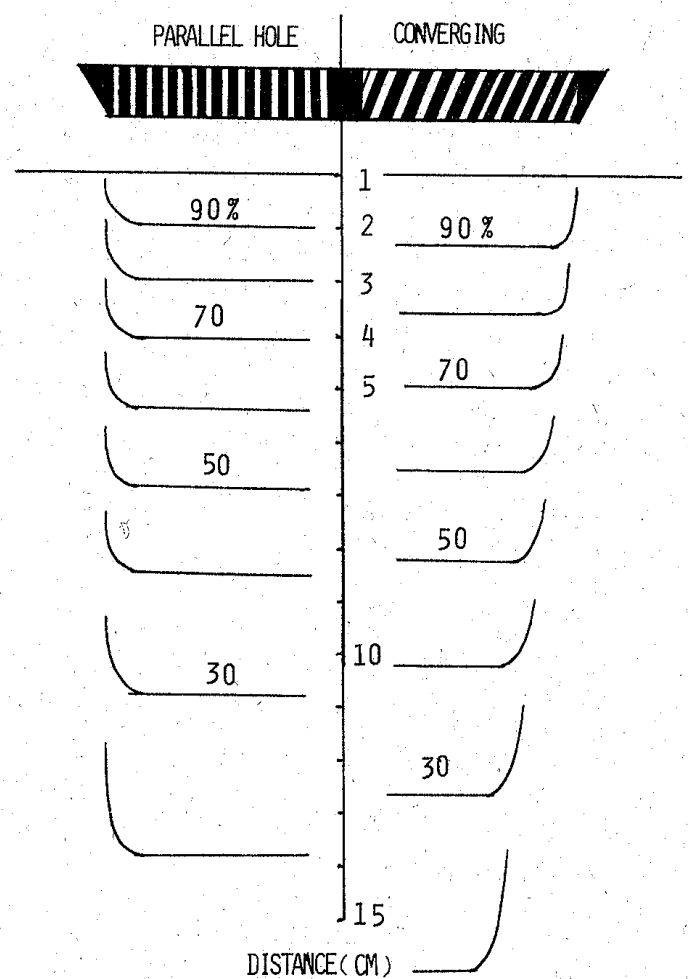

Fig. 18 Iso sensitive curve of parallel hole and converging collimator

等感度曲線である。深さ $10 \mathrm{~cm}$ そ和ける感度はパラレル コリメータが $33 \% ，$ コンバージングコリメータが $41 \%$ と， コリメータの構造に上り深さ方向の感度分布は異なる。

Fig. 19 は平面線源 $\left(10 \times 10 \mathrm{~cm}^{2}\right)$ を利用して求めた吸

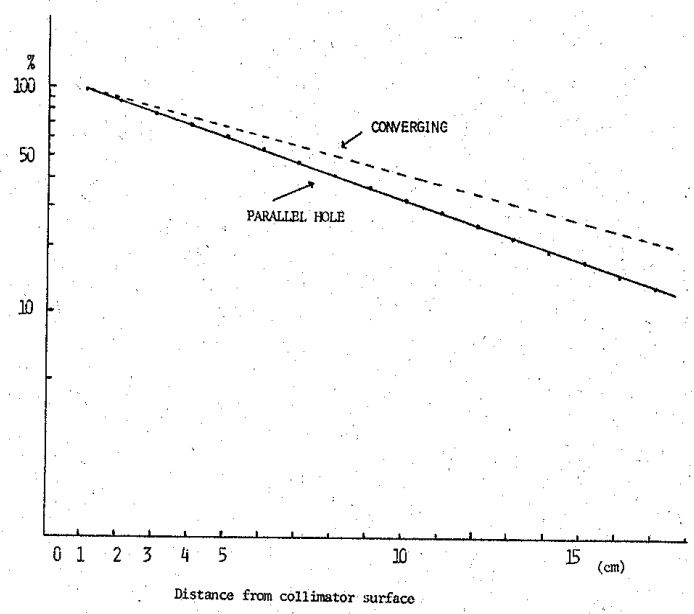

Fig. 19 Central axis decay curve in water 収減弱曲線である。各点移動法に比べ, コリメータの平
面的な感度分布を知ることはできないが，使用核種の深 さによる感度分布は簡単に知ることができる。これらの 図は日常検査にる利用でき，特に投与量の決定和よび深 さ方向のレスポンスの決定に有用である。

\section{3. 均 等、性}

均等性はシンチカメラの性能検査の中でも重要視され る項目である! 均等性の定義和よび測定法も種々の方法 が提案されている。視野の決定について子製作メーカに より視野周辺の処理方法が異なるため湘定可能視野，有 効視野等の表現が異なるが，本検査法では日常使用する 撮影装置で撮影される全視野を有効視野とする。測定に ついても，コリメータ無しの場合の均等性，コリメータ 有りの場合の均等性, 使用する線源飞, 点線源による方 法, 線線源の走查迀方法, 平面線源を利用する方法 等がある。

\section{1 使用材料および作成方法}

コリメータ無しの場合の均等性快点線源を作成し、測 定を行う. 点線源の大きさは $2 \sim 5 \mathrm{~mm} \phi$ 以下とし，放 射能は $100 \mu \mathrm{Ci}$ 前後とする.コリメータ有りの均等性は 平面線源を作成し，测定を行了，平面線源は有効視野上 りも十分に大きな面積を有するものを使用する，放射能 は $2 \mathrm{mCi}$ 前後とする。

\section{2 測定方法}

コリメータ無しの均等性は点線源をクリスタル中心線 上150 200 cm の所湶源を置き（立体角から計算して 全視野か $1 \%$ 以内となる距離)，測定を行了。計数密度 は統計変動を考虑し， $1000 \sim 2000 \mathrm{count} / \mathrm{cm}^{2}$ で測定す る、コリメータ有りの均等性はコリメータ表面と平面線 源間の距離を $1 \mathrm{~cm}$ とし，平行な状態で測定を行う。計 数密度は $1000 \sim 2000 \mathrm{cout} / \mathrm{cm}^{2}$ とする.

\section{3 測定結果および評価方法}

a）写真による評価

Fig. 20 はポラロイドフィルムによる均等性の测定結

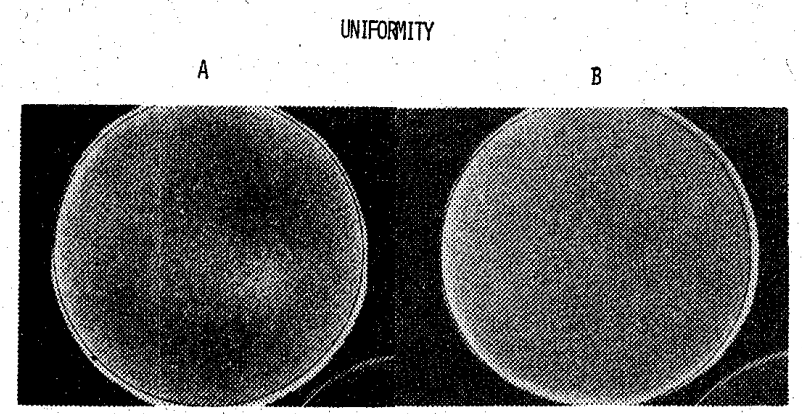

Fig. 20 Uniformity checking photogram

果である.Aは Uniformity 調整前，Bは調整後である。 
ポラロイドフィルムまたはX線フィルムによる評価は最 も簡単であり，均等性の良し悪しが一目で判然とする便 利な方法である.しかし，使用するフィルムの特性上そ の評価には限界がある。特にポラロイドフィルムの場合 には感度が高く，すぐ館和するので，露出条件の設定が その評伍に大きく影響するので注意が必要である。

b）データ処理装置による評価

有効視野内の全視野の画䕀数の統計変動で表示するの が理想的であるが，周辺部の処理方法が問題となるため に有效視野の $80 \%$ 領域（両端を $10 \%$ 切り捨てる) での平 均値に対して最大偏差 $(\%)$ で表示する. 同時に変動係数 (CV) 子併記する. 測定方向はX軸，Y軸の 2 万向にお いて行なう。計算にあたってデータの平滑化は $3 \times 3$ 点 単純移動平均を行なってもよい.(Fig. 21).

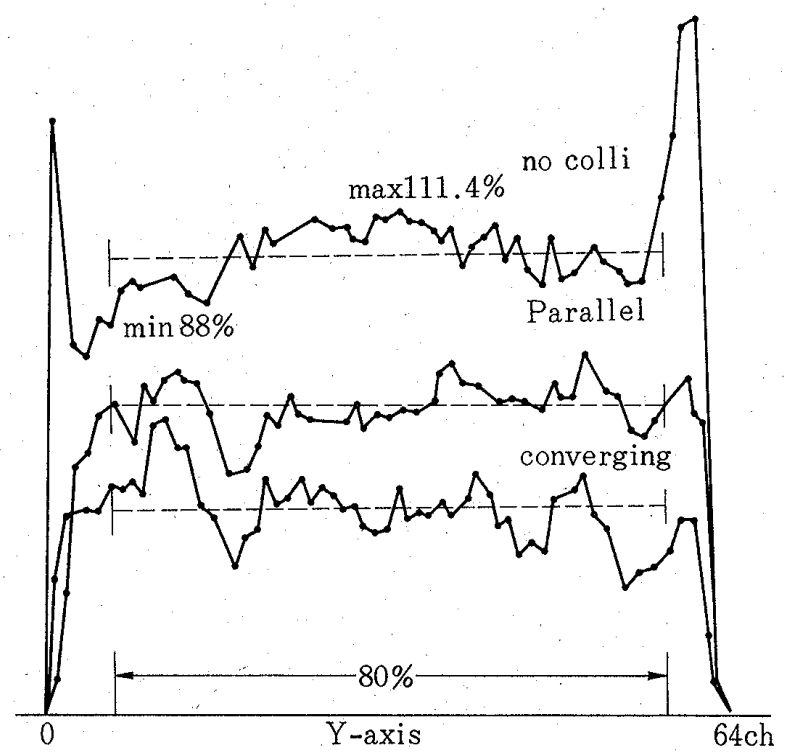

Fig. 21 Uniformity checking curve by channel analyzer

$\mathrm{X}$ 軸，Y軸間の分割する画素間の間隔は，FWHM 以 下であればよく，通常のシンチカメラでは全視野を64， 128 程度に分割すれば十分である。これらの分割された 画素の各カウント数をるって計算する。計算式は下記の 通りである.

平均值 $(\bar{C})=\frac{1}{N} \Sigma \mathrm{Ci}$

分 散 $\left(\sigma t^{2}\right)=\frac{\Sigma\left(\mathrm{C}_{\mathrm{i}}-\overline{\mathrm{C}}\right)^{2}}{\mathrm{~N}-1}$

標準偏差 $(\mathrm{S} . \mathrm{D})=\sqrt{\frac{\sum(\mathrm{C} i-\bar{C})^{2}}{N-1}}$

変動係数 $(\mathrm{CV})=\frac{1}{\bar{C}} \sqrt{\frac{\sum(\mathrm{C} i-\bar{C})^{2}}{N-1}}$

最大偏差 $(\%)= \pm \frac{C_{\max }-C_{\min }}{2 \bar{C}} \times 100$
$C$ : 有效視野 $80 \%$ 内のカウントの平均值

$N$ : 有效視野 $80 \%$ 内の画素数

$\Sigma \mathrm{Ci}$ : 各画素のカウント数の合計

\section{4. 直 線 性}

この方法は直線状の線源を撮影しても曲線状に撮影さ れたり，凹凸状の線に撮影されたりするので，この性能 検查は重要な項目である。特にこの直線性は解像力や均 等性汇関連がある。この検査法には直線状の鉛格子フォ ントムと点または面線源の組合好による方法, 線状線源 の一定間隔の移動撮影，ポイント線源の直線移動による 方法等がある。

本検查法では鉛格子状フォントムによる点線源または 面線源を使用して直線性を測定する。点線源はコリメー タ無しの場合に使用し，面線源はコリメ一タ有りの場合 に使用する。

\section{1 使用材料および作成方法}

鉛格子状ファントムの構造は鉛厚 $5 \mathrm{~mm}$, 直線部分の 溝幅は $2 \mathrm{~mm}$ 以下， 格子間隔は $3 \mathrm{~cm}$ とする．ただし鉛 格子状フォントムのない場合には線状線源を使用する。 線源の長さは有効視野直径より長いものを使用する必要 が岀る、放射能は点線源の場合は $100 \sim 200 \mu \mathrm{Ci}$ ，面線源 の場合には $1 \sim 2 \mathrm{mCi}$ で測定する。

\section{2 測定方法}

鉛格子状ファントムの像は XY 軸䎲平行な像と $45^{\circ}$ の 像をライフサイズのX線フィルムに撮影する. 点線源使 用の場合には距離 $150 \mathrm{~cm}$ 以上上り均一照射し, 面線源 の場合にはコリメータ前面から $10 \mathrm{~cm}$ の距離で鉛格子状 ファントムを撮影する。 カウント数は $300 \mathrm{k}$ カウントで 測定する.

\section{3 測定結果および評価方法}

一般的にはポラロイドフィルム等による目視による評 価が重要視されるが定量的な評価が困難である。曲線の 曲率等の測定によって定量的な評価も理論的には可能で あるがポラロイドフィルム等のフィルムが小さいため実 際上は湘定が困難である. ライフサイズ等の大型フィル ムを使用して撮影すると可能となる。撮影された線は 一定の幅を持って撮影されるのでその中央に中心線を引 きその中心線の偏位で平価する。表現方法は有効視野の 80\%内に拈いて中心線からの最大偏位をンンチレータ西 に换算し，有效視野值径に対する百分率で表す（Fig. 22).

Fig. 23 は XY 軸に平行な像と $45^{\circ}$ の像をライフサイ ズて撮影したものである。平行像に比べ $45^{\circ}$ の像の直線 性が悪いことがわかる，フィルム上での最大偏位は 5 


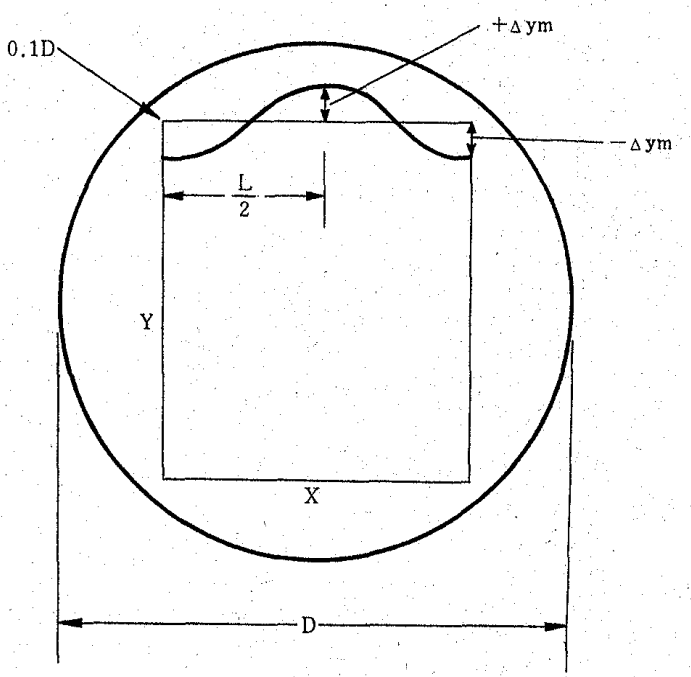

Fig. 22 Determination method of linearity distortion

1) Linesource の長さんとする.

2) $\mathrm{X}$ と $\mathrm{Y}$ の交点は有效視野直径(D) $010 \%$ の 交点とする.

3) $\int \Delta y d x=0$

4) $\Delta y$ は $+\Delta y \mathrm{~m}$ と $-\Delta y \mathrm{~m}$ が存在し， $\Delta y$ は 最高の絶対値を求める。

5）歪多性 $\mathrm{L} / 2$ の值に対する $\Delta y$ の值で， $\mathrm{Y}$ 軸の歪みとする。

6）有効視野の $80 \%$ 内で $\pm \square \mathrm{cm}$ で表示.

LINEARITY

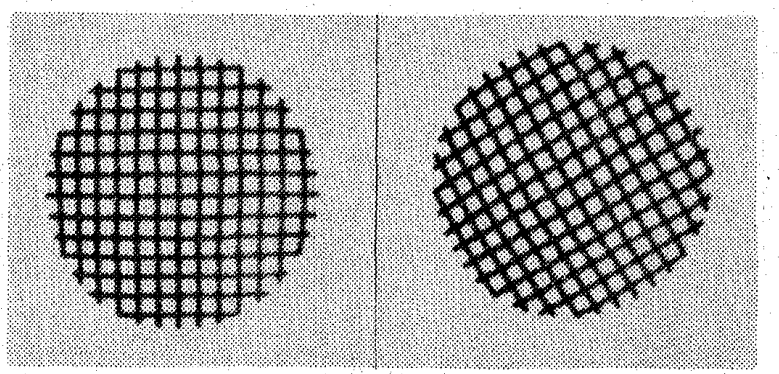

Fig. 23 Linearity checking photogram

$\mathrm{mm}$ でありシンチレータ面に換算すると $7.9 \mathrm{~mm}$ ，有効 視野直径の百分率では $1.9 \%$ でめった。

\section{5. 感度}

シンチカメラの感度測定は検出器自体，コリメータ， 使用核種等によって変化するが高感度であることは臨床 的には投与量の問題，画質の改善等に寄与する。一定の 測定条件で感度測定法を確立することは装㗨間の感度比 較, 感度の経時変化, 撮影条件の決定等浭利である。 この検査法で間題となるのは正確な RI 量の決定が困難 な点が問題として残る. 測定方法には点線源法, 面線源 法，容積線源法を採用する。

\section{1 使用材料および作成方法}

面線源の容器はスキャナの感度測定用ファントムを共 用する $(10 \mathrm{~cm} \phi$, 溶液の深さ $1 \mathrm{~cm}$ 前後)．放射能は500 $\mu \mathrm{Ci}$ (土5\%精度) で測定する。放射能測定にあたり， キューリメータ等を使用する場合には測定器自体の精度 が悪いので充分に校正されたものの使用する必要がある。

\section{2 測定方法}

面線源をコリメータ表面より $10 \mathrm{~cm}$ 離し，中央部にて 全計数傎を測定する。容器とコリメータは平行に設定し て計測する。

\section{3 測定結果及び評価方法}

表現方法は $\mathrm{CPS} / \mu \mathrm{Ci} \cdot \mathrm{cm}^{2}$ で表わす。

Table 4 は LFOV そ HP について測定したもので女 る.

Table 4 Sensitivity of each collimator Sensitivity (CPS $/ \mu \mathrm{Ci} / \mathrm{cm}^{2}$ )

\begin{tabular}{l|l|c} 
& Low energy all purpose pararlel hole & 0.107 \\
\hline LFOV & High resolution converging & 0.106 \\
\hline & High sensitlvity parallel hole & 0.193 \\
\hline HP & High resolution & 0.049 \\
\hline & High sensitivity & 0.160 \\
\hline
\end{tabular}

\section{6. 計数率特性}

シンチカメラの使用傾向として短半減期核種の多量投 与が行なわれている。この場合に使用するシンチカメラ の計数率特性を測定しておくことは正確なデータを得る ためにも重要な検查方法である：単に電気的な分解時間 や1点のみの数落しを測定するのみでなく，各 RI 量 の変化に対可る計数率特性が臨床的には必要である。 計 数率特性はシンチカメラ自体汇計算機等のデータ処理装 置を付属するとその装置のデッドタイムが加わるため， 使用する系全体の計数率特性も知る必要がある。計数率 特性の測定には二線源法，シソクロスコープによるパル 又計測, その他線源增加法, 時間減衰法, 距離の逆二乘 則による方法等がある。本検查法では簡単にできる線源 増加法を採用する。

\section{1 使用材料および作成方法}

水槽をたは水等伍物質 $10 \mathrm{~cm}$ の吸取体を使用儿計数率 特性を求める。 RI 量は最初は $1 \mathrm{mCi}$ づつ $5 \mathrm{mCi}$ まで增 加計測し，以後 $5 \mathrm{mCi}$ づつ $30 \mathrm{mCi}$ まで增加する。 $\mathrm{RI}$ 量は同一試料より希釈法委たは精密天科により重量から 計算して求める. 線源は容積線源（約 $5 \times 5 \times 5 \mathrm{~cm}$ 程度： $125 \mathrm{ml}$ ) を利用する。

\section{2 測定方法}


コリメータ有りの状態で計測する。線源は水槽中に固 定するか，または水等価物質 $10 \mathrm{~cm}$ をコリメー夕線源間 に置き測定与る。測定值は RI 量（ $\mathrm{mCi}$ 数）を横軸に， 縱軸に計数率值 (cps) をプロットしカーブを描く．各測 定値は統計変動の少ない測定值まで計測する。

\section{3 測定結果および評価方法}

シンチカメラ固有の計数率特性を知る上ではコリメー 为無しで測定する倞うが，RI 量が少なくて最高計数率 等子扣さえやすいが，臨床的な応用（投与量の決定など） の点では利用性が少ない. Fig. 24 はコリメータを付け，

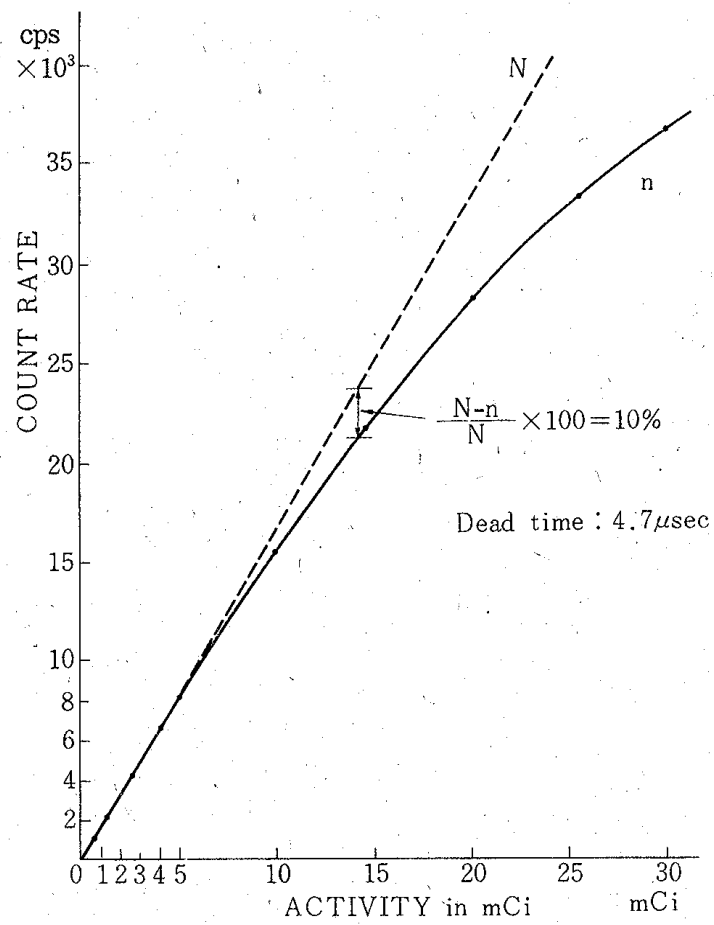

Fig. 24 Characteristic curve of counting rate

吸収体 $10 \mathrm{~cm}$ に括ける計数率特性曲線である。このグラ フより分解時間を求好るために，数艺落しのない低計数 領域 ( $1 \sim 5 \mathrm{mCi})$ を外扦して真の值のを求め, その直 線と測定曲線が10\%離れた俻について分解時間を求める.

$$
\begin{array}{ll}
\tau \fallingdotseq N-n & n: \text { 測定計数率 } \\
N \times n & N: \text { 期得値 }(\text { 真值 }) \\
& \tau: \text { 分解時間 }(\mu \mathrm{sec})
\end{array}
$$

Fig. 5 の分解時間は $4.7 \mu \mathrm{sec}$ である。

\section{7. 固有分解能}

この検查項目はンンチカメラに和故るコメータ以外 の系の分解能を知る目的で検查する。陵床的には総合分 解能が有用で女るが，検出器の構造，電谷系，表示系等 の装置自体の分解能を知るために有用である。この測定 法にはファントム（鉿バーフォントム，アンガーファン
トム等）を利用する方法と FWHM の測定による方法 が女る。本検査法では，鉛バーファントム法と FWHM 法を採用する。

\section{1 鎑バーファントム法}

$\mathrm{XY}$ 平面の 4 象限の鈆バー間隔の買なる物を使用する。 それぞれの鉛バー間隔は使用するシンチカメラの固有分 解幅の前後に $1 \sim 2 \mathrm{~mm}$ 間隔のものを使用した方が良い. 間隔の大さな物を使用するとシンチカメラの分解能が低 下しても検出できない場合がある。

\section{測定方法}

鈆バーフォントムをシンチレータ面に密着して測定す る. 点線源の放射能は100〜200 $\mu \mathrm{Ci}$ とし，150 $200 \mathrm{~cm}$ の距離から均一照射する。イメージ作成の計数密度は $1000 \sim 2000$ count $/ \mathrm{cm}^{2}$ 程度とし，ポラロイド又はX線 フィルムに撮影する。鉛バーファントムは $90^{\circ}$ づ回転. し.4 枚撮影する.

\section{測定結果及び評価方法}

評価方法は有効視野の $80 \%$ 領域で判定する。これはポ ラロイドフィルム又はX線フィルムによる目視での評価 であるため個人差が起こりやすい，そこで評洒の表現法 として，各鉛バー間隔に対して次の表現法を採用する。

例 $a \mathrm{~mm}$ 間隔（全然分解していない）

$b \mathrm{~mm}$ 間瀜（分解していると見る人と分解し

$$
\text { ていないとみる人) }
$$

c mm 間隔（どうやら分解している）

$d \mathrm{~mm}$ 間隔（だれが見ても分解している）

\section{INTRINSIC RESOLUTION}

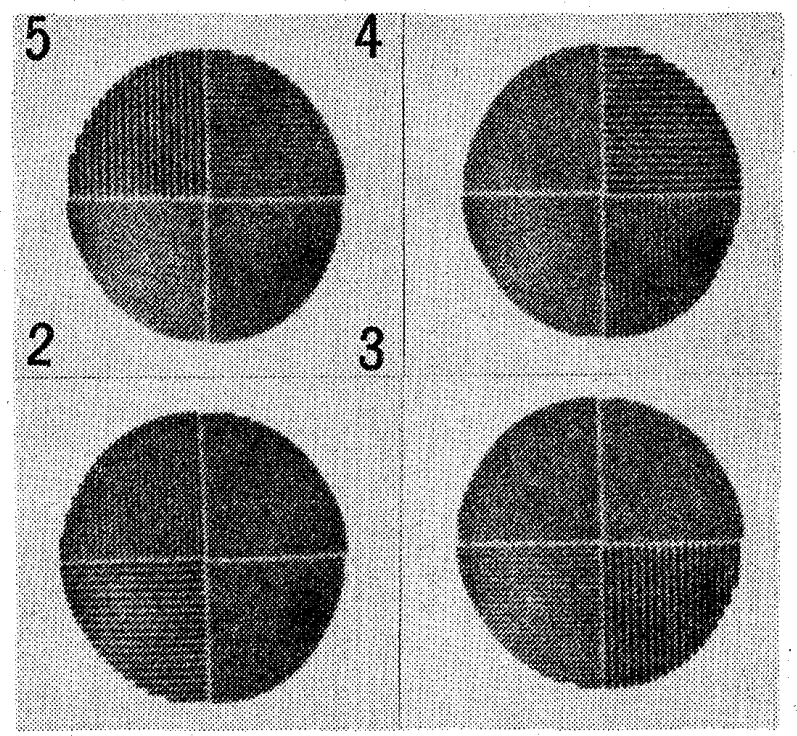

Fig. 25 Intrinsic resolution photogram (bar distance $2 \mathrm{~mm}, 3 \mathrm{~mm}, 4 \mathrm{~mm}, 5 \mathrm{~mm}$ ) 
場合が生ずる可能性があるので，4 像限の内 2 象限以上 め机ば分解しているるのと判定する。

Fig. 25 は鉛バ一間隔 5，4，3，2 mm を使用した時 の固有分解能である. $4 \mathrm{~mm}$ 汇分解されているが $3 \mathrm{~mm}$ は分解されていない，従ってこのカメラの分解能は $3 \sim$ $4 \mathrm{~mm}$ の中間と考兄られる。表現法としては, $3 \mathrm{~mm}(-)$, $4 \mathrm{~mm}(+), 5 \mathrm{~mm}(H)$ で表示する.

\subsection{FWHM 法}

この検査法は計算機屯たはチャンネルアナライザが必 要であり, シンチカメラの分解能を定量的化評価できる 特徴がある. 線状線源を使用し，その幅方向に対する広 がり (線灾答関数) を測定し，そのカーブの半值幅を求 める.

\section{測定方法}

線状線源（内径 $1 \mathrm{~mm}$ ，長さ $40 \mathrm{~mm}$ ) を最低 $5 \mathrm{~cm}$ 厚 の鈆ブロック 2 個でサンドゥィッチにし，その間隔を 2 $\mathrm{mm}$ とする. シンチレータ表面と鉛ブロックの間隔は 5 mmとする (Fig. 26).

測定点は中心部と中央部で計 5 点以上とする。即ちX， Y方向があるので計10点が必要である. 放射能は10〜20 $\mu \mathrm{C}$. で測定する。

各々のカーブの最高点のカウント数は 5000 カウント以 上とし，1つのカーブの測定点数（画素数）は10点以上 が必要である。

\section{測定結果および評価法}

評価は半值幅の值を $\mathrm{mm}$ 表示する，ただし10点の測定 結果がバラック場合には平均值と共に最高値と最低值を 表示する。Fig. 7 の測定結果では，平均值 $7.25 \mathrm{~mm}$, 最高值 $7.9 \mathrm{~mm}$, 最低值 $6.9 \mathrm{~mm}$ である. 鉛バーフォン
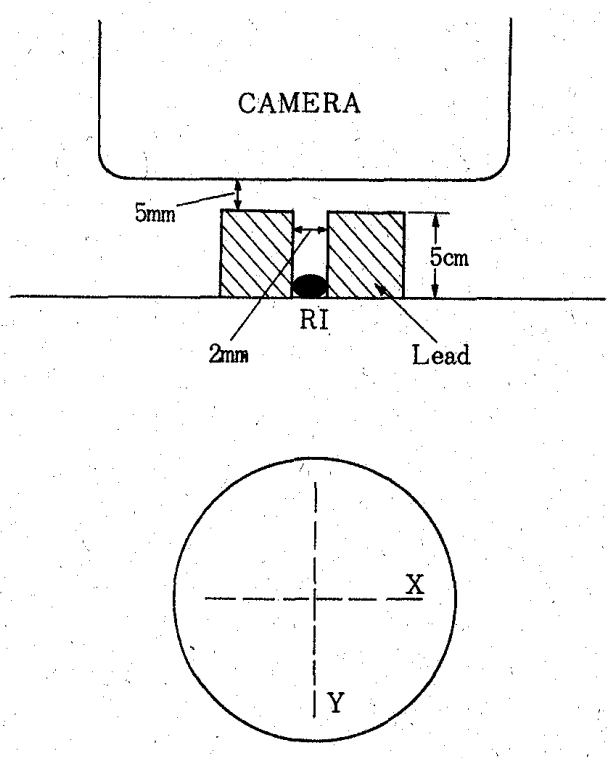

Fig. 26 Out line of spatial resolution (FWHM) measurement
トム法との比較では, バーファントトムの解像度（3〜4 $\mathrm{mm})$ は FWHM 法の約半分の值 $(3.6 \mathrm{~mm})$ が得られる 事から両者の測定値は一致する。

\section{8. 総合分解能}

固有分解能に対して総合分解能があり、コリメータを 装着し，日常の使用条件での分解能を総称して総合分解 能という。この検查法ではテストパターンフォントム法 (鉛パーファントム，アンガーフォントム，肝スライス ファントム，各種蔵器ファントム等）とFWHM 法を採 用する。

\section{1 測 定 法}

本質的には固有分解能の測定法と同じであるが水又は， 水等価物質を使用し，深さ方向の距離の関係として記録 する。ファントムそコリメータ間の吸收体の厚さは，0， $5 ， 10,15,20 \mathrm{~cm}$ と之測定する. FWHM 法は固有分 解能の FWHM 測定法と同じであるが，この場合は鉛 ブロックは使用しない。

\section{2 測定結果および評価方法}

テストパターソフォントム法は，ポラロイドフィルム 等により目視による評価で行う.FWHM は各種コりメ 一タについてグラフで表示する。横軸にコリメータとつ フントム間距離，粉軸に FWHM (mm) を表示する.

(Fig. 27）は IAEA 肝スライスフォントムによる総合 分解能で方る、吸收体 $5 \mathrm{~cm}$ 和よび $10 \mathrm{~cm}$ に括计るシン チグラム像では，LFOV コンバージングコリメータが 最飞解像力が良い事がわかる. HP 高解像力コリメータ は，LFOV 平行型コリメータにくらべ感度は悪いが解 像力は良い. Fig. 28 は LFOV に括汀る各種コリメー

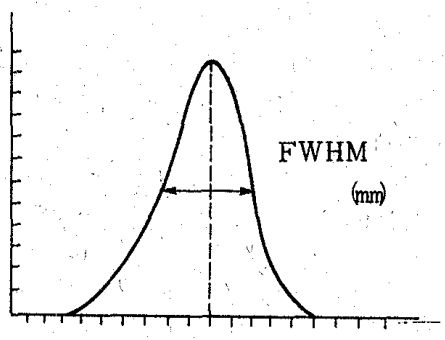

FWHM (mm)

\begin{tabular}{|c|c|c|c|c|c|}
\hline $\mathrm{X}$ & 6.9 & 6.9 & 7.1 & 7.5 & 7.1 \\
\hline $\mathrm{Y}$ & 7.1 & 7.3 & 7.1 & 7.9 & 7.7 \\
\hline
\end{tabular}


LFOV

PARALIER HOLF
LFOV

CONERGING
$H P$

HIGH RESOLUTION

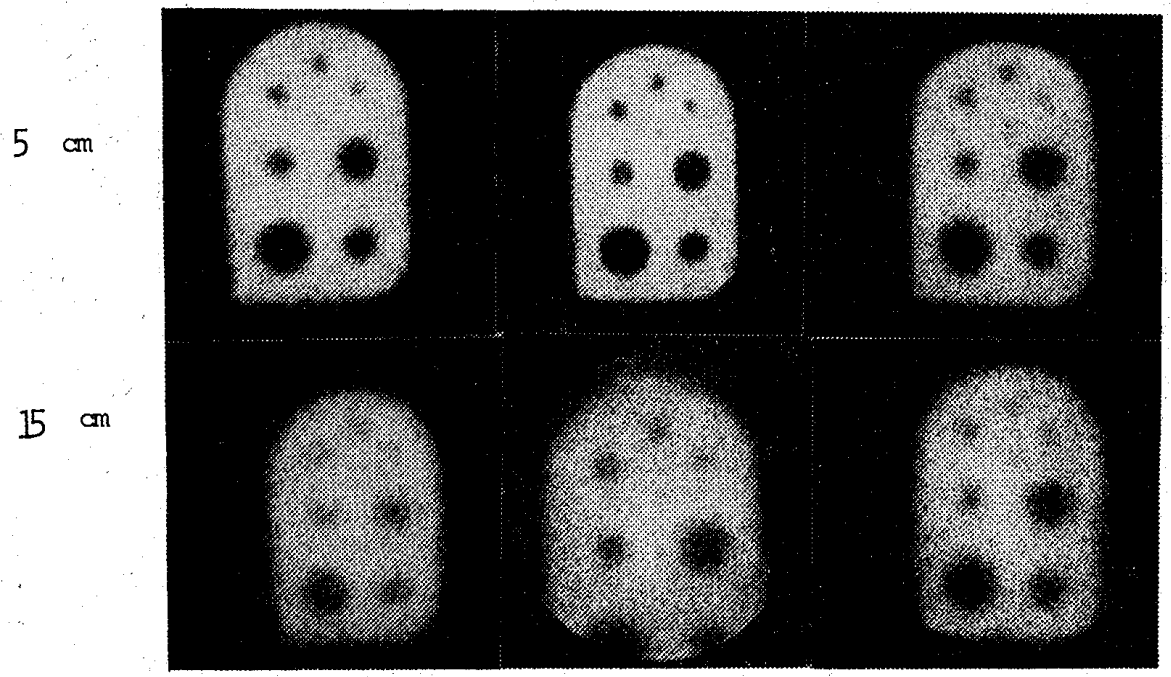

Fig. 27 System resolution checking photogram by IAEA liver slice phantom

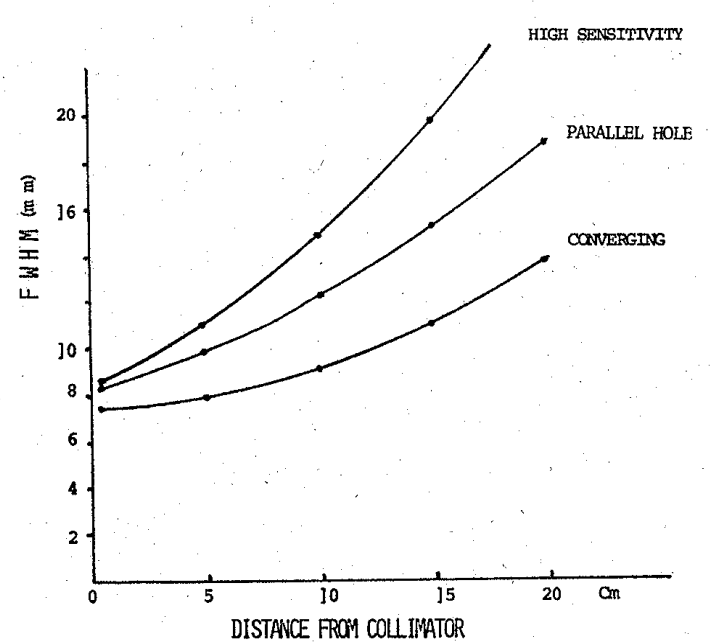

Fig. 28 Spatial resolution (FWHM) of each collimator and distance from collimator

タの FWHM 值である. シンチグラム像同様コンバー ジングコリメータの解像力の良い事がわかる.

\section{9. エネルギー分解能}

使用する装置の核種別のエネルギースペクトルを測定 しておく事はホトピークの形，位置やウィンド幅の決定 に必要である。

\section{1 測定方法}

コリメータの無い状態とコリメータを付忛た時のエネ ルギースペクトルを測定する。コリメータを付けた時の 測定は吸収体 $10 \mathrm{~cm}$ を使用し計測する。線源はコリメー 夕の無い時は点線源 $(100 \mu \mathrm{Ci}$ 前後) を距離 $1.5 \mathrm{~m}$ 以上 ょり均一照射する。コリメータを付けた時は平面線源
（10 $\mathrm{cm} \phi$ 程度）を利用し， $99 \mathrm{~m} \mathrm{Tc}$ の場合は $2 \mathrm{mCi}$ 前後 で測定する，手動によりェネルギースペクトルを取る場 合には，ウインド幅はできるだけ狭く設定し計測する。

\section{2 結果および評価方法}

この測定はデータ処理装置による自動記録法か，又は

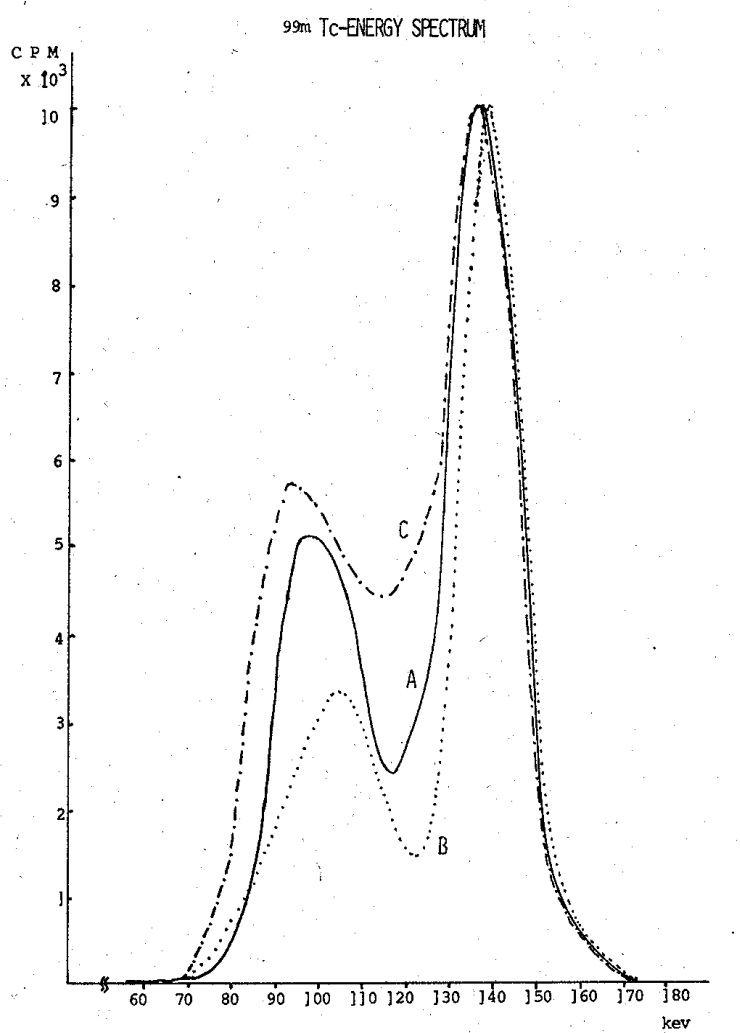

Fig. 29 Tc-99m energy spectrum in no collimator, with collimator and $10 \mathrm{~cm}$ absorber 
手動によりエネルギースペクトルを測定し，ホトピーク の FWHM を測定する，結果は半值幅を $\mathrm{keV}$ で表示す る. (Fig. 29) は，99mTcによるェネルギースペクトル である、Aはコリメータ無し，Bはコリメータを付けた
時，Cは吸収体 $10 \mathrm{~cm}$ を使用した時の各スペクトルであ る. 各ホトピークの FWHMはコリメータ無し, $19 \mathrm{keV}$ (13.5\%)，コリメータを付けた時 $17.5 \mathrm{keV}(12.4 \%)$, $10 \mathrm{~cm}$ の吸収体を使用した時が $25 \mathrm{keV}(17.9 \%)$ である.

\section{III. 動態機能検查装置の性能検査法}

ここで取扱う動態機能検査装置とはレノグラム検査装 置代代表される，単一プロープ型の検査装置に限る、シ ンチカメラ等による動態機能検査についてはシンチカメ ラの項を参照されたい。

\section{1. 使用核種と波高分析器条件の設定}

動態機能検查に使用される核種は多数あるが，この検 查法では低エネルギー核種として $99 \mathrm{mTc}$ ，高エネルギー 核種として 131 さ使用する。エネルギー拉よびウィン ド幅は次の上うに設定する。

$$
\begin{array}{ll}
{ }_{99 \mathrm{~m} T \mathrm{c}} & 142 \mathrm{keV} \pm 10 \%(128 \mathrm{keV} \sim 156 \mathrm{keV}) \\
131 \mathrm{I} & 364 \mathrm{keV} \pm 10 \%(328 \mathrm{keV} \sim 400 \mathrm{keV})
\end{array}
$$

\section{2. 等感度曲線}

この検査は平面㧍よび深さ方向のレスポンスを知る目 的で必要な検査法である。

各コリメータについて等感度曲線を求めて和くと，臨 床検査の場合に目的蔵器末たは組織等からのレスポンス および目的以外からのレスポンスを推察することができ る.

動態機能検查の場合には一般に焦点型コリメータは使 用されないのでシンチスキャナの等感度測定よりは容易 で炙る。

\section{1 測 定 法}

本検查法では点線源の各点移動による方法を採用する。 移動間隔は $1 \sim 2 \mathrm{~cm}$ として最高感度域を $100 \%$ して 10 \%すで測定する。

測定点が多くなる欠点があるために測定間隔を大さく して内挿法で求めても測定結果には余り影響しない，点 線源移動法の他に機械による平面走査や津屋スキャンを 採用しても良い。

ファントムは水または水等価物質を使用して臨床条件 になるべく近い状熊で測定する．その他の測定法はシン チスキャナの等感度測定法に準ずる.

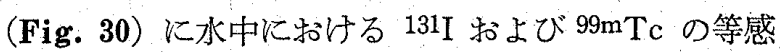
度曲線を示す。(点線源移動法)

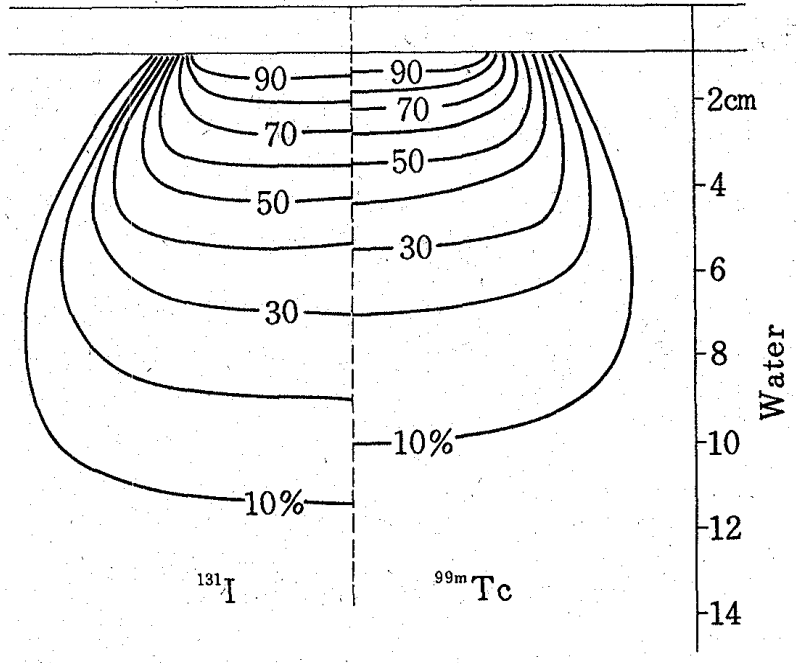

Fig. 30 Iso sensitive curve of I-131, Tc-99m in water

\section{3. 波高分析}

3.1 エネルギ一分解能

3.2 波高分析器の安定性

3.3 エネルギー值線性

以上の項目についてはシンチスキャナの検查方法と同 じである. 参照して下さい.

\section{4. 感度}

動態機能検查装置の感度測定はシンチスキャナ，シン チカメラの感度測定と同じ方法で行ならが，複数の検出 器を同時に使用するので各検出器間の感度比較と感度調 整が重要な因子となる。これらは各検出器の高電圧特性, リニアアンプ特性, PHA 特性, ホトマル拉よびクリス タルの特性が同一でないために起る現象であり，実際の 測定にあたっては，2〜3\%程度の感度差はさけられな W.

動態機能検査では検査部位の目的に合ったコリメータ を選択して使用するので, 各コリメータの感度比較も重 要である.

Table 5 は各コリメータに和惊る感度と, その面積比 
Table 5 Sensitivity of each collimator

\begin{tabular}{l|c|c|c|c|c|c|}
\hline \multirow{2}{*}{ Collimator type } & NaI area & Tc-99 $\mathrm{m}(61 \mu \mathrm{Ci}, 10 \mathrm{~cm} \phi)$ & \multicolumn{3}{|c|}{ I-131 $(54 \mu \mathrm{Ci}, 10 \mathrm{~cm} \phi)$} \\
\cline { 2 - 7 } & & sensitivity & ratio & sensitivity & ratio & \\
\hline $6.2 \times 13 \times 5.7 \mathrm{~h} \mathrm{~cm}$ & $28.26 \mathrm{~cm}^{2}$ & $107 \mathrm{cps} / \mu \mathrm{Ci} / \mathrm{cc}$ & $100 \%$ & $57.8 \mathrm{cps} / \mu \mathrm{Ci} / \mathrm{cc}$ & $100 \%$ & (taper) \\
$8 \phi \times 5.7 \mathrm{~h} \mathrm{~cm}$ & $28.26 \mathrm{~cm}^{2}$ & 108 & 100 & 58.2 & 100 & (taper) \\
$5 \phi \quad \times 5.7 \mathrm{~h} \mathrm{~cm}$ & $19.63 \mathrm{~cm}^{2}$ & 85 & 79 & 46.3 & 80 & (straight) \\
$2.5 \phi \times 5.7 \mathrm{~h} \mathrm{~cm}$ & $19.63 \mathrm{~cm}^{2}$ & 28.5 & 26 & 15.4 & 26 & (taper) \\
$1.25 \phi \times 5.7 \mathrm{~h} \mathrm{~cm}$ & $4.91 \mathrm{~cm}^{2}$ & 0.53 & & 0.29 & & (straight) \\
\hline
\end{tabular}

に詨する感度比較をしめす。

\section{5. 計数率特性}

動態機能検査装置は他の装置に比較してコリメータが オープンであるために感度が高く，数え落し等の計数率 特性が問題となる。（Fig. 31）は $99 \mathrm{mTc}$ の線源増加法 による計数率特性曲線であり，50 kcps 附近より数え落 しが始まっている事がわかる。

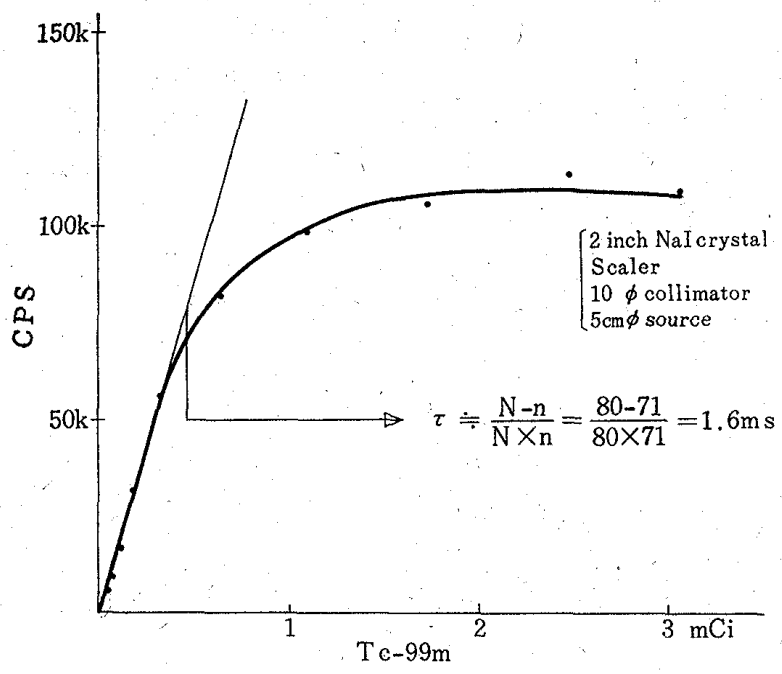

Fig. 31 Characteristic curve of counting rate

この検查法では線源増加法，二線源法を使用するが， 簡単に実験するためには距離の逆二乗法を利用するのも 線源が 1 個ですむ便利さはあるが幾何学的效率が影響し てくるので注意が必要である。

評価法についてはシンチスキャナー，ミンチカメラと 同様であるが，分解時間は一般に真の計数值と測定器の 読值が $10 \%$ 差の生ずる点で求める.

\section{6. バックグラウンド計数と媯蔽能}

動態機能検查では使用する RI 量の少ない事とコリメ 一タの視野が広いためにバックグラウンドの影響を受け やすい，そのために使用前执よび定期的なバックグラウ
ソド測定と遮蔽能のチェックが必要である、特に種々の 方向に検出器を向けて使用寸る場合には，方向依存性む。 チェックする必要がある。

(Fig. 32) はェネルギー別のバックグラウンド計数を しめすे.

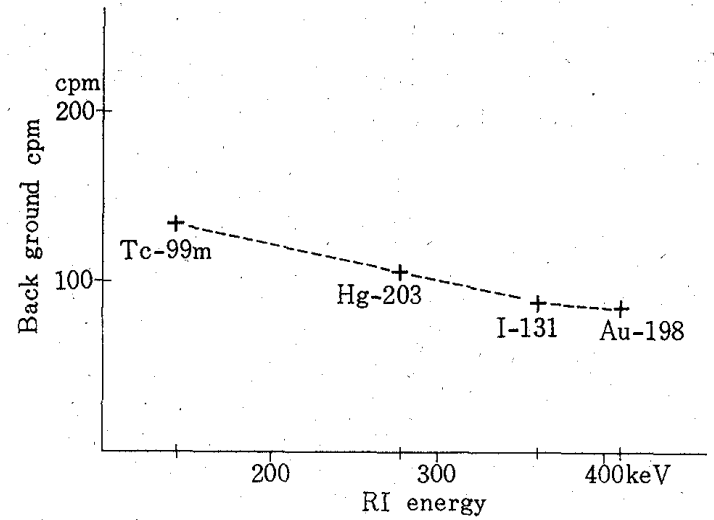

Fig. 32 Back ground value of each energy setting その他の測定についてはシンチスキャナの項を参照し て下さい

\section{7. 信号と記録の応答特性}

動態機能検查の信号の記録方法としては，多くの方法 があるが，最終的な記録方法は各種のペーパーレコーダ とディジタルレコーダに分けられる。

応答特性として問題になるの時間的な応答特性と信 号の高さの応答特性が問題となる。

位置の応答特性はシンチスキャナやシンチカメラの場 合には問題となるが，現在の動態機能検査:装置では問題 にならない.

一般に PHA の出力を Rate Meter を通じてペーパー レコーダに記録する力法が，最も多く使用されているが， 全体の系列より考えるとその特性はペーパーレコーダの 性能に左右される．時間応答特性に影響する因子として， Rate Meter の時定数の設定，ペーパーレコーダの立上 がり执よび立下がり特性が影響する。 
信号の応答特性としては Rate Meter の直線性および ペーペーレコーダの直線性が影響する。

\section{1 測 定 法}

ペーパーレコーダの時間応答には限界があり, 高速現 象を記録する場合には，一般に MT 等に高速記録し， この MTを低速再生してペーパーレコーダに記録する 方法がとられる：時間応答特性の測定法としては，パ サー等を利用して精密測定する方法も学るが，ここでは RI 線源を検出器内に入れたり，出したりすることでの 立上がり特性和よび立下がり特性を求める。

評価方法は実效実定数（フルスゲールの $1 / e=37 \%$ ） になるまでの時間を測定する（Fig. 33）.

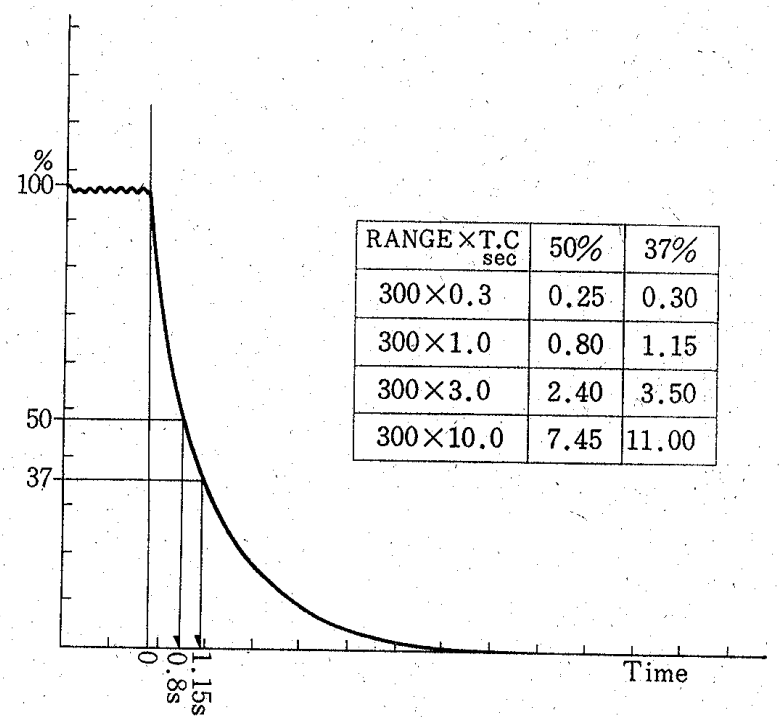

Fig. 33 Signal response check method of recording system

信号の応答特性は 3 種類以上の RI 綄源を用意して， その RI 量とペーパーレューダのふれの高さを測定して， 信号と RI 線源量との直線性を調べる。

\section{文献}

1) Gerald J. Hine (ed.) : Instrumentation in nuclear medicine, Vol. 1 Academic Press, New York (1967).

2）斎藤，渡部：アイソトープスキャニソグに用いられ るコリメーターの検査法.

Radio Isotopes: 17, (2), 23-25, (1968).

3) William H. Blahd. M. D., : Principles of Measurement of Radioactivity and Instrumentation, 46-48, Nuclear Medicine, Mc Graw-Hill, (1965).

4) Yen Wang. M. D.,: Collimators, 13-16, Clinical Radioisotope Scanning, Charles C Thomas Publi. sher, (1967).
5）筧，入江，平松：臨床核医学，40-46 朝倉書店, (1967).

6)上田，飯尾：核医学臨床生理診断法，30-32，医歯 薬出版，(1971).

7）安浩内，石川：シンチグラム装置，臨床放射線，13， (16), 441-456, (1968).

8）渡边克司：シンチスキャナーとその基礎的問題；診 療放射線技術選書 8，50-69，南山堂，(1973).

9）山崎文男他： ラジオアイソトープ講義と実猊，6365, 丸善, (1967).

10）山崎文男他：アイソトープ便覽，449-455，丸善， (1974).

11） C. E：クルートヘイム著, 用田龟本訳：応用ガンマ 線スペクトロメトリー，42-44，産業図畫，(1967).

12) G. J. Hine : Evaluation of forcused collimator performance : Digital recording of line-source response. Int. J. Appl. Radiat. Isotopes 18, 815-823, (1967).

13) G. J. Hine, et al. : Evaluation of forcused collimator performance : Three and five-inch diameter collimators for I-131 and. Tc-99m. Medical Radioisotope Scintigraphy, Vol. 1, Vienna I.A.E.A. 487-507, (1967).

14) Characteristics and test conditions of radionuclide imaging devices, SC 62 C, IEC, 11-13, (1976).

15）小川岩雄 : 放射線 (Radiation) コロナ社，254-255, (1964).

16) Adams R, Zimmerman D., : Methods for calculating the deadtime of anger camera systems, J. Nucl. Med. 14, 496-499, (1973).

17) Freedman GS, Kinsella T, Dwyer A : A correction method for high count rate quantitative radionuclide angiography, Radiogy, 104, 713-715, (1972).

18) Buginger TF : High counting-rate performance of Anger scintillation camera J. Nucl. Med .14, 383-384, (1973).

19) Wang. Y. : Instrumentation. Clinical radioisotope scanning : Ed. by Lewis E, Etter, Charles C, Thomas Publisher, (1967).

20) Ross, R. D and Cradduck, T. D. : Line source response function measurements and modulation transfer function calculation performed on some Nuclear-Chicago and Ohio-Nuclear collimators. Medical Radioisotope Scintigraphy. Vol. 1, 
Vienna I.A.E.A. 437-455 (1969).

21) Christie, J. H., Maclntyre, W. J. : A comparison of line spread function of five and eight-inch collimators with three inch and tapered bore collimators. Medical Radioisotope Scintigraphy, Vol. 1, Vienna I.A.E.A. 457-472 (1969).

22）松平他：シンチグラム記録表示の標準化，日放技学 誌 32(1)，44-61，(1976).

23) Henry N, Wagner. JR : Imaging devices, Principles of nuclear medicine, W. B. Saunders Company, 193-200, (1968).

24）柴山孝行他：シンチカメラの陰性腫瘍検出機序の研 究(第 1 報)，日放技学誌，30(6)，571-581，(1974).

25) 核医学診断機器一覧 (1)，アイソトープニュース, 282, 35-36, (1977).

26）加藤秀起 : シンチスキャナーのコリメーターの統計
䛊差による分解能低下とInformation Density の関 係，日放技学誌，32(1)，15-19，(1976).

27）相沢他：シンチスキャナー用コリメーターの MTF， Radioisotope, 22(9), 48-51, (1973).

28）蜂谷他：Line source 法によるシンチスキャナー用 コリメーターの分解能の検討 (第 1 報，第 2 報)，日 放技学誌 $27, \mathbf{2 9}(2)$,

29）第 33 回総会会員研究会発表抄録：日放技学誌，33 (3)，323-324，(1977).

30）能野，掛川：大型高分解能ガンマカメラの開発，神 奈川核医学研究会誌 $4,19 \sim 21 ，(1975)$.

31）有水, 他：大型高解像カシンチカメラの臨床使用経験, とくに $99 \mathrm{mTc}$-フチン酸による肝シンチグラム，核 医学, 14(1)，137-138，(1977).

32）橿尾英次：シンチスキャナ，放射線測定装置 $(\mathrm{V})$, Radioisotopes, 20 (5)，56-92，(1971).

\section{体外測定装置の性能検査法（抄）}

\section{※シンチスキャナーの性能検査法}

〔1]使用核種と波高分析器条件の設定 使用核種

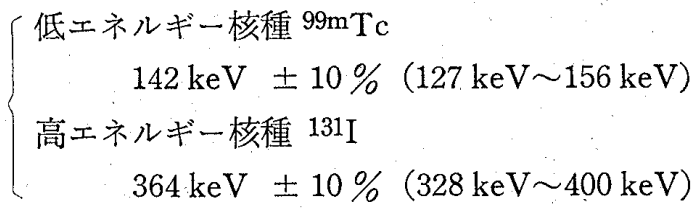

[2] 等感度曲線

2-1 点線源移動法

$10 \mu \mathrm{Ci}$ 前後の点線源 $(2 \mathrm{~mm} \phi)$ を移動して， 各点の計数值を\%表示する.

10\% 100\%の感度曲線を求める.

水中および空中での感度曲線を求める.

2-2 津屋スキャン法

点線源移動法と同じ方法を採用する。

スキャン速度は各装置の最低スピード，片送り スキャン，スキャロッピングの発生しない時定

数の設定が必要である.

\section{[3] 波高分析}

3-1 エネルギー分解能

99mTc と 131I についてウンドウ10\%に設定し， $\gamma$ 線のスペクトルを求め，これより光電ピーク の半値幅を求める.

3-2 波高分析器の安定性
使用時間 8 時間を目安として光電ピークの変動 を測定する。

3-3 エネルギー值線性

$99 \mathrm{mTc} ， 131 \mathrm{I}$ 以外に適当なエネルギーの核種を 追加して光電ピークのベースライン電压と $\gamma$ 線 エネルギーの関係をグラフで示す。

[4] 感度 $\mathrm{cps} / \mu \mathrm{Ci} / \mathrm{cc}$

平面線源（円筒状容器 $10 \mathrm{~cm} \phi$ 前後, 溶液の深 さ $1 \mathrm{~cm}$ 前後）で全体量が $100 \mu \mathrm{Ci}$ （士5\%以 内の精度）を使用する。

測定点は焦点型コリメータは焦点距離, その他 はコリメータ表面より線源中心までの距離を10 $\mathrm{cm}$ とする.

[5]計数率特性（数光落し，分解時間の測定） 5-1 二線源法 :

$$
\begin{aligned}
& \tau=\frac{n_{1}+n_{2}+n_{12}-n_{b}}{n^{2}{ }_{12}-n_{1}{ }^{2}-n_{2}{ }^{2}} \mu \mathrm{sec} \\
& \text { コリメータなし } n_{1}, n_{2}, n_{12} \text { は } 10^{6} \text { カウント } \\
& \text { 以上 }
\end{aligned}
$$

5-2 線源増加法 : 測定距離はクリスタル表面より20 $\mathrm{cm}$ 前後の一定距離に線源を置き，この線源を順 次増加して，この計数值を求める.

横軸にキューリ数，緃軸に計数率をプロットし， 計数率曲線を作成する。低計数率領域より外挿で 
真の值を定め実測値と真の値から次式より分解時

間を求める

$$
\mathrm{N}=\frac{n}{1-n \tau}
$$

[6] 総合分解能

6-1 テストパターン法（バーフォントム，スターファ ソトム，臟器フォントム）は使用する装置の最っ とも分解能の良い条件を選択する。

6-2 FWHM 法：ラインソース $(2 \mathrm{~mm} \phi, 1.5 \mathrm{~cm}$ 前 後）で $\max$ カウントが $10^{5}$ カウン 卜程度になるような線源を使用。

6-3 二線状線源法 : ラインソース 2 本の分解可能幅 を求める(ダブルピークを検知 できる最少幅）

[7] バックグランド計数と遮蕕能

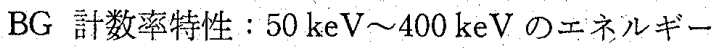
領域をウィンドウ幅10\%に設定 して各エネルギー別のバックグ ラント計数值を求める.

遮 蔽 能：点線源を使用してコリメータを 装着した状態で検出器の外壁表 面を密着して各点の遮蔽能を計 測する.

［8]信号々記録の応答特性（時間応答，位置応答，計 数値応答特性)

スキャン速度, 時定数, 計数率, レートダウン, 計数率一濃度特性, 計数率々打点特性

〔9]焦点型コリメータ

幾何学的評価方法（焦点距離，幾何学的分解能， 感度)

〔10〕スキャン速度

移動速度測定，走查の蛇行，ピッチムラ

\section{※シシチカメラの性能検査法}

〔1]使用核種々波高分析器条件の設定

使用核種 低エネルギー核種 $99 \mathrm{mTc}$

$142 \mathrm{keV} \pm 10 \%(127 \mathrm{keV} \sim 156 \mathrm{keV})$

（但し高エネルギーュリメータ使用の 場合には $131 \mathrm{I}$

$364 \mathrm{keV} \pm 10 \%(328 \mathrm{keV} \sim 400 \mathrm{keV})$

で代用する）

\section{[2]，等感度曲線}

$2-1$ 点線源移動法

点線源 $(2 \mathrm{~mm} \phi$ 程度の球屯たは円筒）

放射能は $1 \mathrm{mCi}$ 前後で計測值を統計変動の少 ない値まで測定する。
水槽中での感度分布を測定する，100\% 10\% まで求める。

[3] 均等性

均等性を䛨価する視野の範囲は日常使用する撮 像装置で撮影される全視野を測定する（有効視 野とする)

3-1 平面線源（有効視野よりも充分に大きな物を使用 する)

コリメータと平面線源の水平面を平行に保つ事 ( $1 \mathrm{~cm} の$ airgap)

計数密度は $1000 \sim 2000$ count $/ \mathrm{cm}^{2}$ （1点の測定 値が統計変動の少ない計数值)

$3-2$ 点数源

コリメータのない場合の評価法である。

点線源（ $2 \sim 5 \mathrm{~mm} \phi$ 以下）をクリスタル中心 線上の 150 200 cm（立体角から計算して全視 野が $1 \%$ 以内）に線源を置く.

計数密度は 1000 2000 count $/ \mathrm{cm}^{2}$ （測定時間， 統計変動，数兄落しを考虑して RI 量を決める) 3-3 栖価方法

：写真による評価はフィルムの特性曲線に注意 する，特にポラロイドフィルムは撮影条件に よって大きな差が生ずる。

: データ处理装置による評価では全視野内の画 素の統計変動で表示するのが理想的であるが， 周辺部の処理が問題となるための有効視野の $80 \%$ 領域の平均値に対して最大偏差（\%)で表 示する.

: データの平滑化は $3 \times 3$ 点単純移動平均を 1 回行なっても良い。

：X軸，Y軸方向の二方向についても評価寸る。

[4]直線性

鉛格子状ファントムを使用して点線源（コリメ 一タなし）または面線源（コリメータあり）で 測定する.

鉛格子状フォントムの構造は鉛厚 $5 \mathrm{~mm}$, 直線 部分の溝幅は $2 \mathrm{~mm}$ 以下，格子間隔は $3 \mathrm{~cm}$ と する。

但し鉛格子状フォントムのない場合には線状線 源を使用しても良い（線源の長さは有効視野直 径よりも長いこと).

評価はフィルムで行ない，像の中央部に中心線 を書きその偏位で評価する。

[5] 感 度

面線源（10 $\mathrm{cm} \phi$, 溶液の深さ $1 \mathrm{~cm}$ 前後)，放 
射能（土5\%精度）

測定点はコリメータ表面より $10 \mathrm{~cm}$ の中央部に 面線源を置き，先の時の全計数值を測定する。 表現方法は $\mathrm{cps} / \mu \mathrm{Ci} / \mathrm{cc} \doteqdot \mathrm{cps} / \mu \mathrm{Ci} / \mathrm{cm}^{2}$

[6] 計数率特性

6-1 線源増加法

コリメータ有りの状態で水槽中のコリメータ表 面より $10 \mathrm{~cm}$ の所に線源 $(1 \sim 30 \mathrm{mCi})$ て測定 する。

横軸に $\mathrm{mCi}$ ，緃軸に cps とし，測定値は統計 変動の少ない計測時間を設定する.

分解時間は数㝋落しのない低計数領域を外插し て真の值を求める $\tau \div \frac{\mathrm{N}-n}{\mathrm{~N} \times n} \mu$ sec 数え落しの 率は次の式で求める $\frac{\mathrm{N}-n}{\mathrm{~N}} \times 100 \%$

[7] 固有分解能

7-1 鉛バーフォントム法

$\mathrm{XY}$ 平面の 4 象元の鉛バー間隔の異なる物を使 用する。但しその間隔は使用するシンチカメラ の固有分解幅を前後に $2 \sim 5 \mathrm{~mm}$ 間隔とする。

: 固有分解能……点線源 $(150 \sim 200 \mathrm{~cm}$ 離す） を使用して鉛バーフォントムをコリメータ表 面に密着して測定する。

: コリメータ装着分解能……面線源を使用する. イメージ作成の計数密度は1000 2000カウント $/ \mathrm{cm}^{2}$ 程度とする。

鉛バーファントムは90度づつ回転して 4 枚撮影 する。

評価は有効視野の $80 \%$ 領域で行ない $\ominus \oplus \oplus \oplus$ で目視竓価する。

\section{7-2 FWHM 法}

線状線源（内径 $1 \mathrm{~mm} \phi$ ，長さ $40 \mathrm{~mm}$ ) を鉛ブ， ロック（5cm 厚）2 個でサンドイッチしてその 間隔 $5 \mathrm{~mm}$ とすする。

測定点は中心部と中央部 4 点で計 5 点以上とす る。即らX，Y方向があるので計10点が必要で ある.

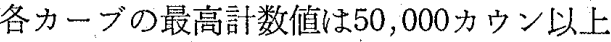

1 つのカーブの測定点数は10点以上

俨価は半值幅の值の $\mathrm{mm}$ 表示

[8] 総合分解能

日常の使用条件での分解能を調べる（水槽また は水等価物質を使用して深さ方向の分解能を測 定守る)

: テストパターンフォントム法（鉛バーフォン
トム, アンガーファントム，各蔵器フォント

么等)

: FWHM 法

[9] エネルギー分解能

各核種別のエネルギーFWHM 求める（ウィ ソドウ幅 $5 \%$ １0\%設定して土ネルギスペクト

儿求める)

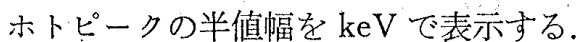

[10] その他

\section{※動態機能検査装置の性能検査法}

〔1]，使用核種そ波高分析器条件の設定

使用核種

$$
\begin{aligned}
& \text { 低エネルギー } 99 \mathrm{~m} \mathrm{Tc} \\
& 142 \mathrm{keV} \pm 10 \%(127 \mathrm{keV} \sim 156 \mathrm{keV}) \\
& \text { 高エネルギー } 131 \text { I } \\
& 364 \mathrm{keV} \pm 10 \%(328 \mathrm{keV} \sim 400 \mathrm{keV})
\end{aligned}
$$

[2]等感度曲線

\section{2-1. 点線源移動法}

シンチスキャナの検査法と同じ（測定点を少な くして内挿法で求めても良い)

\section{[3] 波高分析}

3-1 エネルギー分解能

3-2 波高分析器の安定性

3-3 エネルギー直線性

シンチスキャナの検査法と 同じ.

〔4]感 度

平面線源使用，シンチスキャナの検查法と同じ.

[5]計数率特性

二線源法，線源増加法，シンチスキャナの検査 法と同じ.

〔6] バックグランド測定

シンチスキャナ検査法と同じ.

[7] 信号と記録の応答特性

PHA 出力とレートメータの応答性のチェック （時間执よび電気的特性）

レートメータとレコーダの応答性のチェック

（時間和よび電気的特性）

測定法は電気的なテストパルスを利用して立上 がり，立下がりの応答特性を測定する。

俨価方法は実効時定数（フルスケールの $1 / e=$ 37\%) まで落ちるまでの時間をストップウォッ チで測定する。

その他， MT，PT の記録，再生の計数值，時 間の応答特性を測定する。 